\title{
Doctrina de los juzgados de lo mercantil en sede concursal
}

\author{
Fernando Gómez Martín \\ Auditor y Censor Jurado de cuentas \\ Profesor de Derecho concursal de la Universidad de Deusto \\ Miembro correspondiente de la Real Academia de Ciencias \\ Económicas y Financieras
}

Recibido: 21.06 .06

Aceptado: 10.10 .06

\begin{abstract}
Resumen: Durante cerca de dos años, transcurridos desde la introducción del nuevo concurso de acreedores, el 1 de septiembre de 2004, fecha de entrada en vigor de la Ley 22/2003, de 9 de julio, concursal, se han planteado numerosas dudas interpretativas, algunas resueltas por los Juzgados de lo Mercantil, aunque pendientes de revisión por Tribunales Superiores, sin que conozca aún la doctrina de las Audiencias Provinciales. He intentado concretar algunas cuestiones, particularmente concernientes a la administración concursal, y las opiniones de un sector de la doctrina científica y de los Congresos de Derecho Mercantil, así como las Resoluciones disponibles de dichos Juzgados especializados, que presento en la web <http://www.fgm.net/>, para quienes deseen consultar sus textos íntegros.
\end{abstract}

Palabras clave: Ley 22/2003. Derecho concursal. Juzgados de lo mercantil.

Abstract: During the passed two years, since the introduction of the new «winding-up» legal framework, when the Law 22/2003 (July the 9th), Concursal, took effect the 1st of September 2004, many interpretation doubts have arised. Some of those doubts were happily solved by the Commerce Courts, although most of them are yet pending from revision by Superior Courts. About the previously mentioned doubts, we neather know the doctrine and reaction of the Provincial Courts (second instance in Spain). I have tried to concrete some questions, in particular, concerning the Administrator (Administracion Concursal), and the opinions of part of the scientific doctrine and the Congresses about Commerce Law, as well as the available Resolutions of these specialized Courts, that I present/display in the Web Site <http://www.fgm.net/>, for those who wish to consult the complete texts.

Key words: Winding-up. Commerce law. Commercial Courts.

Sumario: 1. Presupuestos.-2. Solicitud. 2.1. Legitimación. 2.2. Solicitud de concurso de la herencia. 2.3. Solicitud de concurso de varios deudores conjuntamente.-3. Efectos de la declaración de concurso. 3.1. Acumulación de concursos. 3.2. Conservación o venta de la masa activa. 3.3. Continuidad o cese de actividades. 3.3.1. Pago de créditos contra la masa. 3.4. Formulación de cuentas anuales. 3.5. Acciones de responsabilidad y medidas cautelares contra administradores, liquidadores, etc. 3.6. Prohibición de iniciación de nuevos juicios declarativos. 3.7. Continuación y acumulación de juicios declarativos pendientes. 
3.8. Prohibición de ejecuciones singulares, judiciales o extrajudiciales, y de seguirse apremios administrativos o tributarios. 3.8.1. Acción directa ex artículo 1597 del Código Civil. 3.8.1.1. Nuevo concurso de acreedores. 3.8.1.1.1. Masa pasiva. 3.8.1.1.1.1. Créditos concursales. 3.8.1.1.1.2. Clasificación de créditos. 3.8.1.1.2. Masa activa. 3.8.1.2. Recapitulación. 3.9. No compensación. 3.10. Vigencia de los contratos con obligaciones recíprocas y resolución por incumplimiento. 3.11. Contratos de trabajo. 3.12. Acumulación de juicios de desahucio. 3.13. Ejercicio de acciones rescisorias de actos perjudiciales para la masa activa.-4. Informe de la administración concursal. 4.1. Comunicación de créditos. 4.2. Plazo para la presentación del informe de la administración concursal. 4.3. Ausencia de documentos para informar. 4.4. Masa activa. 4.4.1. Inventario. 4.4.1.1. Saldos deudores de la Hacienda Pública. 4.4.1.2. Gravámenes, trabas y cargas. 4.5. Masa pasiva. 4.5.1. Fecha de referencia de la lista de acreedores. 4.5.2. Contenido de la lista de acreedores. 4.5.2.1. Retribución de los administradores concursales. 4.5.2.2. Periodificación de créditos por retenciones de IRPF y para la TGSS. 4.5.2.3. Periodificación del IVA. 4.5.2.4. Facturas rectificativas del IVA. 4.5.2.5. Créditos sometidos a condición resolutoria o suspensiva. 4.5.2.5.1. Crédito bancario por efectos descontados. 4.5.3. Clasificación de créditos 4.5.3.1. Clasificación de créditos afianzados. 4.5.3.2. Clasificación de los salarios de tramitación, posteriores a la declaración de concurso, de las pagas extraordinarias. 4.5.3.3. Clasificación del crédito tributario y de la Tesorería General de la Seguridad Social. 4.5.3.3.1. Privilegio general ex art. 91.4. 4.5.3.3.2. Recargos. 4.5.3.3.3. Clasificación del crédito tributario, caso de convenio concursal. 4.5.3.4. Clasificación de los créditos por trabajo personal no dependiente. 4.5.3.5. Privilegio especial del instante del concurso necesario. 4.5.3.6. Leasing y Renting. 4.5.3.6.1. Suspensión y clasificación de intereses. 4.5.3.7. Créditos comunicados tardíamente. 4.6. Formulación de cuentas anuales por la administración concursal. 4.7. Presentación de informe de la administración concursal. 4.8. Impugnación del inventario y de la lista de acreedores. 4.8.1. Impugnación de créditos contra la masa. 4.8.2. Demandas incidentales de impugnación.

Desde el 1 de septiembre de 2004, fecha de entrada en vigor de la Ley 22/2003, de 9 de julio, concursal, hasta el 31 de diciembre de 2005, se han declarado en España 1006 concursos de acreedores ${ }^{1}$. Cataluña ha sido la Comunidad Autónoma con más concursos en segundo lugar, la Comunidad de Madrid y en tercera posición, el País Vasco. Durante el primer trimestre de $2006^{2}$, el número de concursos publicados en el Boletín Oficial del Estado ascendió a 263 frente a los 192 que se produjeron en el mismo período de 2005.

${ }^{1}$ Boletín del Registro de Economistas Forenses, n. ${ }^{\circ}$ 205, de 19 de enero de 2005.

${ }^{2}$ El Confidencial.com, 27.04.2006. 
La media anual de procedimientos de suspensiones de pagos y quiebras admitidos y declarados, durante la década 1994-2003, fue de 967, y en el año 2003 ascendió a $1.012^{3}$; éstos datos permiten deducir que el nuevo procedimiento concursal no ha influido en un aumento de las insolvencias declaradas. Indirectamente, puede considerarse que la profunda reforma concursal, según la exposición de motivos de la ley concursal, pese a su unidad legal (un solo texto que regula aspectos materiales y procesales), de disciplina (igual tratamiento de las situaciones concursales de todos los deudores, con independencia de su carácter o condición civil o mercantil) y de sistema (único proceso), y a la flexibilidad del nuevo procedimiento concursal, no ha calado aún en la cultura empresarial, pues el empresario no utiliza esta herramienta de gestión para intentar la solución de dificultades económico-financieras, quizá por el estigma que conlleva la obligada publicidad judicial.

Esta valoración se confirma con los datos obtenidos en naciones de nuestro entorno. Así, respecto del año 2000, las declaraciones judiciales de insolvencia $^{4}$ fueron del orden de 35.000 en Alemania, 60.000 en Francia, 15.000 en Italia, y 45.000 en el Reino Unido, aunque no sean datos homogéneos por tratarse de legislaciones que regulan procedimientos concursales de saneamiento (Alemania), de reorganización (USA y RU), de acuerdo amistoso (Francia), o de reconversión (Italia). En el año 2004, 33.200 empresas se declararon insolventes en Estados Unidos, según un estudio de Seguros de Créditos Euler Hermes ${ }^{5}$.

Durante los dos años transcurridos, desde la vigencia del nuevo concurso de acreedores, se han planteado numerosas dudas interpretativas de la referida Ley, que han sido resueltas por los Juzgados de lo Mercantil, algunas pendientes de revisión por Tribunales Superiores, sin que conozca aún la doctrina de las Audiencias Provinciales. La anterior mención a los Juzgados de lo Mercantil proporciona la ocasión para el reconocimiento a los Magistrados correspondientes, por el gran esfuerzo profesional que vienen realizando, con una carga de asuntos desproporcionada a los medios personales y materiales que disponen, así como por el alto nivel de especialización jurídica de sus resoluciones. En general, la valoración del nuevo concurso de acreedores es positiva ${ }^{6}$.

En las notas que siguen, trataré de concretar algunas de las dudas a que me refería, particularmente concernientes a la administración concursal ${ }^{7}, y$

\footnotetext{
${ }^{3}$ Instituto Nacional de Estadística.

${ }^{4}$ Research of Entrepreneurial Environment by Creditreform Economic Research Unit.

${ }^{5}$ Expansión, 1 de junio de 2005.

${ }^{6}$ Fernández Pelaz, M., El Diario Vasco, 15 de diciembre de 2004; García-VillarruBIA, M., Cinco Días, 01/09/2005; AGÜERA Marín, B., «La Ley concursal cumple dos años», Técnica Económica, n. ${ }^{\circ}$ 175, pp. 57-63, Colegio Central de Titulados Mercantiles de Madrid.

${ }^{7}$ Gómez Martín, F., Administración Concursal, Valencia, Ed. CISS, 2004.
} 
las opiniones de un sector de la doctrina científica y de los Congresos de Derecho Mercantil, celebrados por los Jueces Especialistas, en Valencia, los días 9 y 10 de diciembre de 2004 y 1 y 2 de diciembre de 2005, así como las Resoluciones de los Juzgados de lo Mercantil disponibles, aunque dada su extensión he preferido «guardar»y ofrecerlas en la web <http://www.fgm.net/>, para quienes deseen consultar sus textos íntegros. Dicho exceso de paginación aconseja diferir la materia relativa al convenio y a la liquidación, así como el tratamiento de la calificación, para su posterior publicación, si la Dirección de la Revista lo tiene a bien.

\section{Presupuestos}

Sobre el presupuesto subjetivo (art. 1), es posible la declaración de concurso de sociedades irregulares, así como de Agrupaciones de Interés Económico ${ }^{8}$ : «Se entendió que es posible la declaración de concurso de la sociedad mercantil irregular, sin perjuicio de que la aplicación a la misma de las normas de la sociedad colectiva (artículo 16.2 de la Ley de Sociedades Anónimas) imponga la extensión a los socios de la responsabilidad por las deudas de la sociedad (artículo 48.5 de la Ley Concursal, en relación con el artículo 237 del Código de Comercio), lo que quedaría confirmado por la previsión del art. 24.3 de la Ley Concursal en relación al art. 322 del Reglamento del Registro Mercantil. Asimismo se entendió posible la declaración de concurso de las Agrupaciones de Interés Económico reguladas por la Ley 12/1991, de 29 abril 1991, dado que las mismas sí tienen personalidad jurídica conforme resulta del art. 1 de dicha ley, y pueden por tanto ser declaradas en concurso, como resulta corroborado por el art. 18.10-3 y 20 de dicha ley, en la redacción dada por la Disposición Final 25 de la Ley Concursal».

Se reconoce el presupuesto objetivo (art. 2) en caso de insolvencia del deudor común, y define la insolvencia actual como el estado en que se encuentra el deudor que no puede cumplir regularmente sus obligaciones, y la inminente ${ }^{9}$, como el estado del deudor que prevea que no podrá cumplir regular y puntualmente sus obligaciones. El incumplimiento regular parece referirse a la imposibilidad de hacerlo con los recursos normales (ingresos habituales del tráfico negocial), sin acudir a recursos extraordinarios (enajenación o gravamen de bienes o derechos no dedicados a dicho tráfico), y el incumplimiento puntual puede relacionarse con la previsión de no poder atender las obligaciones a su vencimiento, sean exigibles o contingentes.

${ }^{8}$ CONCLUSIONES DEL PRIMER ENCUENTRO DE LA ESPECIALIDAD MERCANTIL, celebrado en Valencia los días 9 y 10 de diciembre de 2004.

${ }^{9}$ El Juzgado de Primera Instancia n. ${ }^{\circ} 10$ (Mercantil) de Santander, por Auto de fecha 7 de diciembre de 2004, declara un concurso voluntario por insolvencia inminente. 
Aunque no he encontrado en la Ley regulación expresa, conviene recordar que un deudor sólo podrá ser declarado en concurso si se acredita la existencia de pluralidad de acreedores ${ }^{10}$, pues si hubiese un solo acreedor procedería la ejecución singular.

\section{Solicitud}

A la solicitud de declaración de concurso se dedican los arts. 5 (deber de solicitar el concurso voluntario); 6 (requisitos de la demanda de concurso voluntario); y 7 (declaración de concurso necesario).

Se dispone el deber de solicitar la declaración de concurso voluntario, dentro del plazo de dos meses siguientes a la fecha en que hubiera conocido o debido conocer su estado de insolvencia, que se presume cuando han transcurrido los plazos señalados en el mencionado art. 2.4.4. ${ }^{\circ}$ (art. 5), como destaca la exposición de motivos: «El deudor tiene el deber de solicitar la declaración de concurso cuando conozca o hubiera debido conocer su estado de insolvencia; pero tiene la facultad de anticiparse a éste».

\subsection{Legitimación}

Para solicitar la declaración de concurso están legitimados el deudor y cualquiera de sus acreedores, así como los herederos de la herencia, sus acreedores y su administrador judicial (art. 3), con las excepciones previstas en las Disposiciones finales decimoctava ${ }^{11}$ y vigesimoséptima ${ }^{12}$ de la Ley.

En las conclusiones del primer encuentro de la especialidad mercantil, celebrado en Valencia, los días 9 y 10 de diciembre de 2004, se aborda la legitimación de los órganos de administración de las sociedades mercantiles para solicitar la declaración de concurso y, en particular, si en las SRL es preceptivo el acuerdo de la Junta de socios.

\subsection{Solicitud de concurso de la herencia}

El art. 3.4 legitima para solicitar la declaración de concurso de la herencia a los acreedores del deudor fallecido (necesario), a los herederos del finado y al administrador de la herencia (voluntario), y en este apartado se exi-

${ }^{10}$ Se menciona este requisito en el Auto, de fecha 3 de diciembre de 2004, del Juzgado de lo Mercantil número 1 de Bilbao.

${ }^{11}$ Reforma de la Ley del Mercado de Valores. Se modifica el art. 76 bis de la Ley 24/1988, de 28 de julio, del Mercado de Valores.

${ }^{12}$ Reforma de la Ley de Ordenación y Supervisión de los Seguros Privados. Se modifica el art. 37 de la Ley 30/1995, de 8 de noviembre, de Ordenación y Supervisión de los Seguros Privados. 
ge al instante que los datos de la memoria se refieran al causante, como resulta evidente, pues se trata del deudor.

El Auto del Juzgado de lo Mercantil n. ${ }^{\circ} 4$ de Madrid, de fecha 21 de julio de 2005, resuelve sobre legitimación de la sindicatura de la quiebra para solicitar la declaración de concurso de la herencia, así como otras cuestines de interés.

\subsection{Solicitud de concurso de varios deudores conjuntamente}

El concurso voluntario se inicia a solicitud del deudor, según dispone el art. $6^{13}$. Sin embargo, parece que la Ley concursal no contempla la solicitud de concurso conjunto de varias personas (acumulación subjetiva de acciones).

Creo que no se ha solucionado del todo la problemática del tratamiento concursal de personas vinculadas, excepto cuando se pruebe la responsabilidad patrimonial entre ellas y respecto de la acumulación de procesos, es decir, sigue sin concretarse la acumulación subjetiva de acciones o solicitud conjunta de concurso voluntario de varios deudores, aunque se pruebe su vinculación patrimonial (sociedades sin personalidad jurídica, grupos de empresas, etc.), como se observa en las conclusiones primer encuentro de la especialidad mercantil, celebrado en Valencia, los días 9 y 10 de diciembre de 2004.

Sin embargo, el Auto del Juzgado de lo Mercantil n. ${ }^{\text {o }} 3$ de Barcelona, de 15 noviembre de 2004, en el Fundamento de Derecho segundo, se inclina por una interpretación integradora del artículo 25 y el 3.5 de la Ley que permitiera la solicitud conjunta de concursos de empresas de un mismo grupo y su tramitación coordinada, al objeto de que por los mismos administradores concursales se asuman las responsabilidades de ambos concursos, en el sentido de realizar el informe de las sociedades afectadas y realizar las funciones propias de la administración en ambos concursos, atendiendo a las circunstancias del grupo y a los intereses que pudieran corresponder a los acreedores de cada una de las entidades concursadas.

De igual modo, el Auto del Juzgado de lo Mercantil n. ${ }^{\circ} 1$ de Vitoria-Gasteiz, de fecha 11 de marzo de 2005, en el Fundamento de Derecho segundo, considera que no existe razón para rechazar la declaración conjunta de concurso de las dos sociedades, siendo la primera titular de todo el capital de la segunda, y no mediando problemas competenciales.

También, el Juzgado de lo Mercantil n. ${ }^{\circ} 1$ de Cádiz, en Auto de fecha 7 de abril de 2006, resuelve la cuestión que se plantea, respecto de la que no hay unanimidad entre los Jueces de lo Mercantil, y radica en determinar si el

${ }^{13}$ El Juzgado de lo Mercantil de Santander, por Auto de fecha 13 de diciembre de 2004, inadmite la solicitud de concurso voluntario, por falta de aportación de la documentación establecida en el artículo 6 de la Ley Concursal. 
art. 3.5 LC puede extenderse a supuestos de concurso voluntario, es decir, si se considera admisible la posibilidad de que el deudor pueda solicitar la declaración de concurso, en este caso, de varias sociedades del mismo grupo. La Ley concursal no contempla esta posibilidad en el art. 3.5, pero tampoco la prohíbe, debiendo tenerse en cuenta razones prácticas y de economía, ya que de inadmitirse la solicitud, deberían tramitarse los concursos por separado, nombrando administraciones concursales distintas en cada uno de ellos, siendo así que posteriormente, conforme al art. 25 LC, dichos concursos resultarían acumulables a instancias de la administración concursal, habiéndose duplicado actuaciones que podrían haberse evitado ad initio con una interpretación más flexible.

El apartado 5 del art. 3 contempla dos supuestos: el primero, cuando el acreedor lo sea de varios deudores personas naturales y entre ellos exista confusión de patrimonios, es decir, posean en comunidad la titularidad de bienes y derechos que respondan de sus respectivas obligaciones, o cuando respondan personal y solidariamente ${ }^{14}$, con todos sus bienes, de obligaciones de terceros (v.g. socios colectivos y herederos que hayan aceptado la herencia pura y simplemente o sin beneficio de inventario, según el art. 1003 del Código Civil); y, el segundo, si el acreedor lo es de varias personas jurídicas deudoras, que forman parte de un grupo, con identidad sustancial de sus miembros, es decir, con socios significativamente comunes, y sometidos a dirección unitaria. Al parecer, se regula la posibilidad de solicitar el concurso necesario de varios deudores para su declaración en un solo proceso concursal, en el que se determinará una masa activa conjunta y una masa pasiva colectiva. No observo mayores dificultades en supuestos de deudores personas naturales, caso de confusión patrimonial, o grupos jerárquicos (control), pero tengo algunas dudas respecto a los grupos paritarios u horizontales de sociedades (personas jurídicas), independientes unas de otras, aunque agrupadas voluntariamente para determinados fines estratégicos.

Aunque referido a la competencia internacional y territorial, el apartado 4 del art. 10 regula el supuesto de declaración conjunta de concurso necesario de varios deudores.

\section{Efectos de la declaración de concurso}

La Ley concursal dedica el Título XIII a los efectos de la declaración de concurso sobre el deudor, los acreedores, los contratos y los actos perjudiciales para la masa activa.

14 «Artículo 127. Todos los socios que formen la Compañía colectiva, sean o no gestores de la misma, estarán obligados personal y solidariamente, con todos sus bienes, a las resultas de las operaciones que se hagan a nombre y por cuenta de la Compañía, bajo la firma de ésta y por persona autorizada para usarla». 


\subsection{Acumulación de concursos}

La exposición de motivos se ocupa, muy de pasada, de la acumulación de autos, salvo en lo relativo a sociedades de responsabilidad ilimitada: «Original es, también, respecto del derecho anterior, la regulación de los efectos del concurso de la sociedad sobre los socios subsidiariamente responsables de las deudas de ésta, que se reduce a atribuir a la administración concursal la legitimación exclusiva para ejercitar la correspondiente acción una vez aprobado el convenio o abierta la liquidación. Se evitan así tanto la extensión automática del concurso a personas que, aun responsables de las deudas sociales, pueden ser solventes, como las reclamaciones individuales de los acreedores contra los socios, perturbadoras del buen orden del concurso».

Según el art. 25.1, en el concurso de persona jurídica, cuando se trate de sociedad colectiva o comanditaria, será posible la acumulación a éste de los concursos declarados de los socios solidariamente responsables de las deudas sociales, así como en supuestos de sociedades irregulares, y si el concursado fuese sociedad de responsabilidad limitada habrá de probarse que sus socios, miembros o integrantes son personalmente responsables de las deudas sociales.

En el concurso de sociedad dominante de un grupo, podrá declararse la acumulación a éste de los concursos de las sociedades dependientes. Los administradores concursales conocerán que se ocupan del concurso de una sociedad dominante de un grupo prima facie, como consecuencia de la documentación aportada por el deudor $e x$ art. 6.3.4. ${ }^{\circ}$, aunque podrán consultar el art. 87 del TRLSA.

$\mathrm{Al}$ respecto, el Auto del Juzgado de lo Mercantil n. ${ }^{\circ} 3$ de Barcelona, de 15 noviembre de 2004, en el Fundamento de Derecho Segundo.

Duque Domínguez ${ }^{15}$ señala que la administración concursal podrá solicitar, mediante escrito razonado, la acumulación al procedimiento ya declarado de la sociedad dominante de los concursos ya declarados de las sociedades dominadas pertenecientes al mismo grupo, pero plantea las siguientes interrogantes:

«¿Cuáles serán los efectos de la acumulación? Si el intérprete se atiene al art. 84 LEC, los procedimientos acumulados se sustanciarán en el mismo procedimiento o por los mismos trámites "y se decidirán en la misma sentencia" ¿Quiere esto decir que se produce una reunión de todos los patrimonios de las entidades agrupadas, teniendo que participar los acreedores de las sociedades concursadas con una clasificación común de créditos? Por ello, sería conveniente que se aclararan estas cuestiones, para

${ }^{15}$ Duque domínguez, J. F., «Problemas del concurso de grupos de empresas», Jornadas sobre la reforma del Derecho concursal español (7 al 11 de octubre de 2002), Documento n. ${ }^{\circ} 5$ del Registro de Economistas Forenses del Consejo General de Colegios de Economistas de España, Madrid, octubre 2002, pp. 158-160. 
evitar consecuencias excesivas al no haberse declarado que se sustancien en procedimientos separados. La acumulación de procesos en el concurso seguirá los trámites de la LEC (arts.74-98). Pero ¿no sería posible que el acreedor pidiera una acumulación de acciones (arts. 71-73), proponiendo ante el juez competente para conocer el concurso de la sociedad dominante el concurso de las sociedades dominadas, ya que entre todos los sujetos pasivos existe "un nexo por razón del título o causa de pedir" (art. 72 LEC)? Y en el caso de que no quepa esa posibilidad, ¿no sería conveniente que se previera así en el PLC? Por otro lado, ¿cuál será la solución cuando se haya declarado sólo el concurso de sociedades dependientes y todavía no se haya declarado el concurso de la dominante?».

En la Ley concursal, no he encontrado respuesta a estas cuestiones, aunque en la práctica, respecto de la primera, se separan las masas activas y pasivas de las diferentes sociedades declaradas en concurso único, dentro del informe de la administración concursal ex art. 75. Sobre acumulación de acciones, como luego se concretará, algunos Juzgados de lo Mercantil han admitido la solicitud conjunta de concurso voluntario de la matriz y sus filiales.

El art. 10, dedicado a competencia internacional y territorial, en el segundo párrafo del apartado 4, contempla la tramitación de concursos acumulados.

Continúa el art. 25: «2. También podrán acumularse, a solicitud de la administración concursal de cualquiera de ellos, los concursos de quienes sean miembros o integrantes de una entidad sin personalidad jurídica y respondan personalmente de las deudas contraídas en el tráfico en nombre de ésta».

Parece que puede servir de orientación hermenéutica la doctrina que estudia las sociedades civiles y comunidades de bienes, etc., cuando carezcan de personalidad jurídica, así como las sociedades irregulares. Estas sociedades irregulares carecen de personalidad jurídica, propia e independiente de la de sus socios, por no haberse inscrito en el Registro Mercantil, como exigen los arts. 119 del C. de C., 7 del TRLSA y 11 de la LSRL. Un amplio sector de la doctrina afirma que a las sociedades irregulares mercantiles por su objeto debe serles de aplicación el régimen propio de las sociedades colectivas (Broseta ${ }^{16}$; Sánchez Calero ${ }^{17}$; Vicent Chuliá ${ }^{18}$, que cita a Alonso Ureba y Girón Tena; y Uría $\left.{ }^{19}\right)$. A la misma conclusión

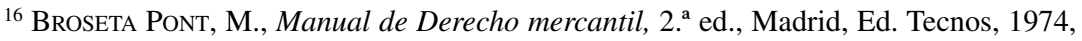
pp. 153-154.

${ }^{17}$ SÁNCheZ CAlERO, F., Instituciones de Derecho mercantil. 15. ${ }^{\text {a }}$ ed., Madrid, Editoriales de Derecho Reunidas, 1991, pp. 163-164.

${ }^{18}$ Vicent Chuliá, F., Compendio crítico de Derecho mercantil, 3. a ed., Barcelona, Ed. Bosch, 1991, vol. I, pp. 334-343. Introducción al Derecho mercantil. 8. ${ }^{\mathrm{a}}$ ed., Valencia, Tirant lo blanch, 1995, pp. 150-151.

${ }^{19}$ UríA, R., Derecho mercantil, 22. a ed., Madrid, Ed. Marcial Pons, 1995, pp. 166-167. 
llega la SAP de Zaragoza, de 16.02.1998. Sánchez Paredes ${ }^{20}$ realiza un estudio monográfico en el que pone de manifiesto el hecho de que la LSA, al establecer los presupuestos legales para la calificación de una sociedad como irregular, no se limita a reconocerla como una realidad jurídica dotada de efectos particulares y específicos sino que, además, la ha provisto de una regulación propia encaminada a la defensa de los intereses de socios (facultados para instar la disolución) y terceros (posibilidad de subsumir la sociedad anónima irregular en el régimen de la sociedad colectiva o, en su caso, en el de la civil). Idéntica conclusión formula Valpuesta Gastamin$\mathrm{za}^{21}$, cuando destaca que la sociedad irregular es una sociedad absolutamente normal y el estigma de la irregularidad no alcanza sino a los efectos de la inoponibilidad de lo no inscrito y a la ilimitación de la responsabilidad de los socios. De la Cámara Álvarez ${ }^{22}$ estima que la nueva LSA ha venido a zanjar implícitamente la cuestión, al remitirse a las normas de la sociedad colectiva cuando la sociedad anónima no inscrita opere, a pesar de que conste la voluntad deliberada de no inscribir o de haber transcurrido un año desde la fecha de la escritura, sin que ésta se haya presentado en el registro. Aborda el tratamiento de las sociedades anónimas constituidas en documento privado y defiende la tesis de su conversión en sociedad colectiva si su objeto es mercantil, que considera confirmada por el art. 16.2 del TRLSA.

El art. 11.3 de la LSRL de 1995, dispone lo siguiente: «Será de aplicación a la sociedad en formación y a la sociedad irregular lo dispuesto en los artículos 15 y 16 de la Ley de Sociedades Anónimas». Para las sociedades comanditarias por acciones, serán de aplicación los mentados arts. 15 y 16, por remisión del art. 152 del Código de Comercio a la Ley de Sociedades Anónimas.

\subsection{Conservación o venta de la masa activa}

Se establece, en el art. 43, el deber de conservación de la masa activa por el deudor y por la administración concursal, con la prohibición de enajenar o gravar los bienes y derechos que la integren, sin autorización del Juez, hasta la aprobación judicial del convenio o la apertura de la liquida-

${ }^{20}$ SÁnchez Paredes, M. ${ }^{a}$ L., «Introducción a la publicidad registral mercantil de quiebras y suspensiones de pagos». Revista Crítica de Derecho Inmobiliario, núm. 623, julioagosto 1994, pp. 1619-1625.

${ }^{21}$ VAlPuesta GastaminZa, E. M. ${ }^{\text {a }, ~ « A s p e c t o s ~ c o n c u r s a l e s ~ e n ~ l a ~ s o c i e d a d ~ i r r e g u l a r », ~ e n ~}$ Estudios jurídicos en homenaje al profesor Aurelio Menéndez, Madrid, Ed. Civitas, 1996, tomo III, pp. 3646-3647.

22 CÁmara Álvarez, M. de la, «La sociedad en formación-La sociedad irregular», en Derecho de Sociedades, Madrid, Consejo General del Poder Judicial, 1992, pp. 183-207. 
ción, excepto los actos de disposición inherentes a la continuación de la actividad profesional o empresarial del deudor. Sin embargo, el artículo 155.3 y 4 regula la enajenación de bienes y derechos afectos a créditos con privilegio especial y permite la venta de bienes de la masa activa, que garanticen créditos dotados de privilegio especial, durante la fase común del concurso, según Auto del Juzgado de lo Mercantil n. ${ }^{\circ} 4$ de Madrid, de fecha 5 de abril de 2005. Asimismo, el Auto del Juzgado de lo Mercantil n. ${ }^{\circ} 1$ de Madrid, de fecha 27 de abril de 2005. El Auto del mismo Juzgado, de fecha 13 de junio de 2005, que resuelve el recurso de reposición contra la anterior Sentencia, declara la compatibilidad opcional de la subasta y la venta directa.

De igual modo, el Auto del Juzgado de lo Mercantil n. ${ }^{\circ} 4$ de Madrid, de fecha 11 de octubre de 2005, autoriza la venta directa de bienes durante la fase común.

Respecto de la enajenación de participación en capital de otra sociedad, el Auto del Juzgado de lo Mercantil n. ${ }^{\circ} 2$ de Madrid, de fecha 23 de mayo de 2005, autoriza su venta directa durante la fase común.

En relación con la venta de un vehículo automóvil, se pronuncia el Auto del Juzgado de lo Mercantil n. ${ }^{\circ} 4$ de Madrid, de fecha 14 de junio de 2005, que autoriza su venta directa durante la fase común.

Sobre la enajenación de una finca hipotecada, al amparo del art. 155.5 de la Ley concursal, y respecto de su venta directa al oferente a un precio superior al mínimo que se hubiere pactado, el Juzgado de lo Mercantil n. ${ }^{\circ} 1$ de Madrid, mediante Auto de fecha 2 de junio de 2005, autoriza la enajenación, aunque la somete a los siguientes límites: 1) la autorización para la enajenación de tal derecho se otorga con la condición de que el precio de adquisición de tal derecho de propiedad industrial debe ser en todo caso superior a 821.750 euros; 2) que la enajenación se anuncie en todo caso en el tablón de anuncios del Juzgado según lo previsto en el apartado 4 del artículo 155 LC, y de concurrir diversas ofertas de adquisición sobre tal derecho se abrirá licitación, debiendo los interesados en participar consignar la cantidad del $10 \%$ del precio mínimo de enajenación de tal derecho, y adjudicándose al mejor postor; y 3) la enajenación del inmueble gravado se deberá realizar con subsistencia del gravamen, y con subrogación del adquirente en la obligación del deudor que quedará excluida de la masa pasiva (artículo 155.3 LC).

El Juzgado de lo Mercantil de Navarra, por Auto de fecha 17 de noviembre de 2004, autoriza la cesión de ejecución de obras de la urbanización de un plan parcial y la venta de materiales, de forma directa durante la fase común.

También es posible la cesión de los derechos sobre bienes adquiridos mediante arrendamiento financiero, como se autoriza en el Auto del Juzgado de lo Mercantil n. ${ }^{\circ} 1$ de Madrid, de fecha 29 de diciembre de 2005, de forma directa durante la fase común. 
En la Segunda Mesa Redonda ${ }^{23}$ del II Congreso de Derecho Mercantil, celebrado en Valencia, los días 1 y 2 de diciembre de 2005, sobre «Algunas cuestiones relativas al convenio y liquidación», se aborda la siguiente: «Las peticiones de enajenación antes de la fase de liquidación por razón justificada. Autorizaciones judiciales de venta» y se considera factible.

\subsection{Continuidad o cese de actividades}

Se establece el principio general de continuidad de las actividades del deudor, salvo que el Juez acuerde otra cosa. Sobre continuación de la actividad empresarial del deudor, interesa el Auto del Juzgado de lo Mercantil n. ${ }^{\circ}$ 3 de Barcelona, de fecha 28 de diciembre de $2004^{24}$.

Cuando el deudor haya infringido las limitaciones del art. 40, sus actos podrán ser anulados a instancia de la administración concursal, por los cauces del incidente concursal.

Sobre cese de actividades se pronuncia el Juzgado de lo Mercantil de Santander, mediante Auto de fecha 20 de febrero de 2004.

\subsubsection{PAGO DE CRÉDitos CONTRA LA MASA}

Si el deudor mantiene sus actividades empresariales o profesionales, aunque también en casos de cese o inactividad, pueden devengarse créditos a cargo de la masa o contra la masa.

Se observa en el art. 84.1, concordante con el art. 49, que excluye de la masa pasiva, expresamente, los créditos contra la masa, es decir, entre otros, aquellos que la doctrina y la jurisprudencia viene denominando «deudas de la masa» y «créditos prededucibles». El art. 84.2 presenta un meritorio esfuerzo recopilador, para detallar los créditos que integran las deudas contra la masa. Sobre el pago de estos créditos prededucibles, interesa el art. 154.2 y 3.

Ante las dificultades del pago de créditos con cargo a la masa o contra la masa, en la práctica concursal, puede acudirse a lo resuelto por Auto del Juzgado de lo Mercantil n. ${ }^{\circ} 1$ de Madrid, de fecha 24 de junio de 2005, que supera la rigidez de respetar, a todo trance, el orden de los vencimientos de las obligaciones.

Sin embargo, la AEAT, en sus comunicaciones a la administración concursal, advierte: «...se le requiere para que garantice el fiel cumplimiento de

\footnotetext{
${ }^{23}$ Relator: José María Fernández Seijo, Magistrado del Juzgado de lo Mercantil n.o 3 de Barcelona; Intervinientes: Pablo González Carrero Fojón, Magistrado del Juzgado de lo Mercantil de La Coruña, y Edmundo Rodríguez Achútegui, Magistrado del Juzgado de lo Mercantil n. ${ }^{\circ} 1$ de Bilbao.

${ }^{24}$ Anuario de Derecho Concursal 4/2005, Editorial Aranzadi, pp. 392-394.
} 
lo establecido en el artículo 154.2 de la Ley 22/2003, de 9 de julio, Concursal, no autorizando pagos de créditos contra la masa que proponga la empresa si existiesen otros con vencimiento anterior aún no atendidos. Todo ello sin perjuicio de las acciones de responsabilidad que, en virtud de lo dispuesto en el artículo 36 de la Ley 22/2003, de 9 de julio, Concursal, pudieran corresponder por actos u omisiones de los administradores concursales que lesionen directamente los intereses de la Hacienda Pública», y la TGSS es beligerante: «En caso de continuación de la actividad empresarial, subsiste la obligación de cotizar por los trabajadores que continúen de alta en la empresa, por lo que solicitamos nos envíen justificantes de los ingresos efectuados cada mes en concepto de cotización de dichos trabajadores. En el supuesto de que no sea posible hacer frente al pago por no existir liquidez o bienes en la empresa, solicitamos lo comuniquen a esta Subdirección en el plazo más breve posible. Les recordamos que estos créditos serán considerados créditos contra la masa, conforme al artículo 84.1.5 de la Ley Concursal, por tratarse de créditos laborales generados por el ejercicio de la actividad empresarial del deudor tras la declaración del concurso, y que como tales podrán ser reclamados mediante el procedimiento de recaudación previsto por el Reglamento General de Recaudación de la Seguridad Social, en caso de que no se proceda a su debido pago» (sic).

\subsection{Formulación de cuentas anuales}

El art. 46.2 mantiene el deber de formular las cuentas anuales, después de declarado el concurso, que implica el cumplimiento de lo dispuesto en los arts. 25 a 30 y 34 a 39 del C. de C., sobre llevanza contable, y demás concordantes del TRLSA (arts. 171 a 201), en su caso. En el supuesto de intervención, si el deudor no formulase las cuentas anuales, ¿se trasladan estos deberes contables a la administración concursal? No parece, aunque será causa de su petición al Juzgado para requerimiento al concursado.

\subsection{Acciones de responsabilidad y medidas cautelares contra administrado- res, liquidadores, etc.}

Según el art. 48.1, en caso de intervención, los órganos sociales de la persona jurídica deudora conservan las facultades de administración y representación, aunque limitadas, y parece que conservarán facultades de representación, en caso de suspensión, también supeditadas a la decisión de la administración concursal, salvo el supuesto en que, a consecuencia de la apertura de la fase de liquidación, se declare el cese de los administradores o liquidadores. Las sociedades mercantiles declaradas en concurso deben celebrar las juntas generales ordinarias y las extraordinarias que precisen, y sus órganos de administración, cuando constituyan consejo de administración, celebrarán las reuniones pertinentes. Ambos órganos sociales, a cuyas 
sesiones podrán asistir los administradores concursales, con voz y sin voto, adoptarán los acuerdos que estimen oportunos, aunque su eficacia, cuando afecten al patrimonio, estará supeditada a la decisión de la administración concursal o del Juez.

El art. 48.2 se refiere a las acciones de responsabilidad previstas en los arts. 133, 211 y 279 del TRLSA, así como en el art. 69 y concordantes de la LSRL, para cuyo ejercicio se legitima a la administración concursal.

En la Tercera Mesa Redonda ${ }^{25}$ del II Congreso de Derecho Mercantil, celebrado en Valencia, los días 1 y 2 de diciembre de 2005, sobre «La sección de calificación: aspectos procesales y sustantivos», Quinto bloque, la sección de calificación del concurso y las acciones de responsabilidad contra los administradores o liquidadores societarios, se plantean las siguientes cuestiones:

«Problemas de compatibilidad entre el régimen de responsabilidad extraconcursal de los administradores y liquidadores sociales y el régimen de responsabilidad concursal». Se considera que no son excluyentes.

«¿Es diferente la naturaleza de la responsabilidad que se exige a los administradores como consecuencia del ejercicio de las acciones de los arts. 262 de la Ley de Sociedades Anónimas y 105 de la Ley de Sociedades de Responsabilidad Limitada, de la que se exige en la sección de calificación en virtud de lo previsto en el art. 172.2. $3^{\circ}$ y 3 de la Ley Concursal?» Consideran que es distinta. En el primer caso, se trata de una «responsabilidad sanción», por deudas, mientras que, en el segundo caso, se trata de una responsabilidad por daños.

« $i$ Y respecto de la responsabilidad de los administradores sociales regulada en el art. 133 y siguientes de la Ley de Sociedades Anónimas?» Conservan un ámbito propio, en el que no se produce ninguna concurrencia con la responsabilidad concursal.

«Posibilidad de interferencia entre los regímenes de responsabilidad extraconcursales y concursales». Reconocen que, respecto de estas acciones societarias, puede haber un ámbito coincidente con la responsabilidad concursal, aunque les parece difícil que los regímenes de responsabilidad societaria y concursal puedan interferir entre sí.

Sin embargo, el Auto del Juzgado de $1 .^{\mathrm{a}}$ Instancia n. ${ }^{\circ} 10$ y Mercantil de Santander, de fecha 13 de febrero de 2006, considera que las acciones de responsabilidad individual y legal, por deudas, frente a los administradores sociales y liquidadores de hecho o de derecho actuales o de quienes lo fueron dentro de los dos últimos años a la declaración de concurso, resultan impedidas durante la tramitación del concurso.

${ }^{25}$ Relator: Pedro Vela Torres, Magistrado, Juzgado de Primera Instancia-Mercantil n. ${ }^{\circ} 9$ de Córdoba. Intervinientes: Rafael Sarazá Jimena, Magistrado, Juzgado de lo Mercantil de Sevilla, y Enrique Pinazo Tobes, Magistrado, Juzgado de Primera Instancia n. ${ }^{\circ} 14$ y Mercantil de Granada. 
Coincide con la tesis que mantiene el Magistrado García Martínez ${ }^{26}$ : «Pues bien, no menos perturbador puede llegar a ser, una vez declarado el concurso, y existiendo la posibilidad de que el patrimonio de los administradores se vea obligado a responder, en todo o en parte, del fallido concursal, el ejercicio por los acreedores de la acción individual de responsabilidad (si concurre el vínculo de solidaridad antes referido) o de la acción de responsabilidad ex lege».

El art. 48.3 estipula dos requisitos para que el Juez pueda ordenar cautelarmente, de oficio o a solicitud razonada de la administración concursal, el embargo de bienes y derechos de los administradores o liquidadores de derecho o de hecho, y de quienes hubieran tenido esta condición dentro de los dos años anteriores a la fecha de la declaración de concurso de persona jurídica, a saber: fundada posibilidad de que el concurso se califique de culpable y de que la masa activa sea insuficiente para satisfacer todas las deudas. El conocimiento de ambos hechos, por parte del Juez, será más fundado una vez disponga del informe de la administración concursal ex art. 75 .

El Auto del Juzgado de lo Mercantil n. ${ }^{\circ} 1$ de Málaga, de fecha 25 de enero de 2005, analiza algunas circunstancias propicias para la adopción de medidas cautelares.

El mismo Juzgado de Málaga, por Auto de fecha 27 de junio de 2005, decide la adopción de la medida de embargo preventivo de los bienes del administrador de la sociedad concursada, con la novedad del acuerdo relativo a que la administración concursal realice, a efectos de caución, una provisión contable en el informe concursal, por importe de seis mil euros, para responder, en su caso, de los posibles daños y perjuicios que pudieran derivarse de conformidad a lo previsto en los artículos 17 LC y 732 de la LEC.

El Auto del Juzgado de lo Mercantil n. ${ }^{\circ} 2$ de Barcelona, de fecha 18 de julio de 2005, también proporciona algunas claves sobre la justificación de estas medidas cautelares.

El Juzgado de lo Mercantil n. ${ }^{\circ} 5$ de los de Madrid, en el Auto de declaración de concurso voluntario, de fecha 10 de octubre de 2005, acuerda la adopción de medidas cautelares de embargo de bienes y derechos del administrador único de la concursada.

Sin embargo, el Auto de la Sección Quince de esta Audiencia Provincial, de fecha 6 de febrero de 2006, es muy restrictivo en la apreciación del requisito de la apariencia de buen derecho.

\footnotetext{
${ }^{26}$ García Martínez, A., «Declaración de concurso y responsabilidad de administradores en las Leyes de sociedades anónimas y sociedades de responsabilidad limitada», Revista Iuris, Ed. La Ley, núm. 101, enero de 2006, pp. 28-36.
} 


\subsection{Prohibición de iniciación nuevos juicios declarativos}

El art. 50 regula los nuevos juicios declarativos y prohíbe su iniciación una vez declarado el concurso del deudor. Debe acudirse, por tanto, a lo dispuesto en el art. 8, que determina las materias sobre las que la jurisdicción del juez del concurso es exclusiva y excluyente. Estas acciones de demandas declarativas civiles (no las laborales, excepto los expedientes previstos en el art. 64), así como las ejecuciones (cualquiera que sea el órgano que las hubiera ordenado), medidas cautelares, etc., sólo podrán plantearse ante el juez del concurso. El apartado 2 de este precepto parece aclarar que pueden ejercitarse acciones, con posterioridad a la declaración del concurso, ante los juzgados o tribunales de los órdenes contencioso-administrativo, social o penal, aunque cuando pudieran tener trascendencia para el patrimonio del deudor emplazarán a la administración concursal.

Sobre inadmisión de juicio monitorio se pronuncia el Auto del Juzgado de Primera Instancia n. ${ }^{\circ} 1$ de Santander, de fecha 4 de enero de 2005.

\subsection{Continuación y acumulación de juicios declarativos pendientes}

En relación con el art. 51.1 el Auto del Juzgado de lo Mercantil n. ${ }^{\circ} 1$ de Madrid, de fecha 27 de mayo de 2005, resuelve sobre una solicitud de acumulación al proceso concursal de acciones individuales por parte de trabajadores, que se encontraban en tramitación al momento de la declaración de concurso, y decide que la acumulación de los procedimientos en trámite en los Juzgados de lo Social no cabe que sea acordada, porque en ellos ya había recaído Sentencia, que no puede ser revisada por el Juzgado de lo Mercantil, y cuya emisión presupone la celebración de la vista que se constituye como término final para poder acordar la acumulación, según el artículo 77.4 LEC -aplicable al caso en virtud de lo que dispone la Disposición Final Quinta de la LC-. Deduzco que si no hubiere recaído sentencia tampoco cabe su acumulación, pues sólo está prevista para los juicios declarativos de la competencia del Juez del concurso y las acciones individuales de los trabajadores siguen siendo competencia de los Juzgados de lo Social, aunque la ejecución de la sentencia que se dicte queda suspendida $e x$ art. 55 de la Ley concursal.

\subsection{Prohibición de ejecuciones singulares, judiciales o extrajudiciales, y de seguirse apremios administrativos o tributarios}

El art. 55.1 prohíbe, declarado el concurso, la iniciación de ejecuciones singulares, judiciales [que trata el Libro tercero de la Ley de Enjuiciamiento Civil] o extrajudiciales [art. 1872 del Código Civil; art. 635 de la LEC; y, art. 129 de la Ley Hipotecaria], y que se sigan apremios administrativos o tributarios contra el patrimonio del deudor, aunque permite que puedan continuarse aquellos procedimientos administrativos de ejecución en los que se hubiera dictado providencia de apremio y las ejecuciones laborales en las 
que se hubieran embargado bienes del concursado, todo ello con anterioridad a la fecha de declaración del concurso, siempre que los bienes objeto de embargo no resulten necesarios para la continuidad de la actividad profesional o empresarial del deudor.

El Auto del Juzgado de lo Mercantil n. ${ }^{\circ} 1$ de Las Palmas, de fecha 3 de enero de 2005, sobre embargos decretados por la Agencia Estatal de la Administración, por la Tesorería General de la Seguridad Social, por la Consejería de Economía y Hacienda del Gobierno Canario, por la Liga Nacional de Fútbol Profesional, y la Real Federación Española de Fútbol, acuerda que se dejen sin efecto, desde la fecha de declaración del concurso, los embargos que recaigan sobre bienes y derechos de la Unión Deportiva Las Palmas, S.A.D., consistentes en dinero en efectivo o en derechos directamente transformables en dinero en efectivo, tales como patrocinios de Entidades Públicas o Privadas, ingresos por venta de entradas en taquilla, por abonos y por venta de palcos, ingresos por publicidad, traspaso de jugadores y otros análogos, por ser necesarios o afectos a la producción.

El Tribunal de Conflictos de Jurisdicción, en Sentencia de fecha 19 de octubre de 2005, resuelve el conflicto suscitado entre el referido Juzgado de lo Mercantil n. ${ }^{\circ} 1$ de las Palmas de Gran Canaria y la Delegación Especial Agencia Estatal de la Administración Tributaria en Canarias, a favor del primero.

Respecto a cómo podrán continuarse aquellos procedimientos administrativos de ejecución en los que se hubiera dictado providencia de apremio, el Auto del Juzgado de lo Mercantil n. ${ }^{\circ} 1$ de Cádiz, de fecha 3 de mayo de 2005, resuelve que tanto la Tesorería General de la Seguridad Social como la Agencia Estatal de la Administración Tributaria y los Juzgados en los que se sigan ejecuciones deberán comunicar al Juzgado su estado, y si se ha procedido a la suspensión o, en caso contrario, si se continúa por concurrir la excepción, y ello sin perjuicio de que por la recurrente, caso de no estar conforme con la decisión en cada caso del Juzgado, se proceda a plantear el conflicto de jurisdicción, como insinúa en el escrito de recurso.

Se ocupan de esta cuestión en las conclusiones del Primer Encuentro de la Especialidad Mercantil, celebrado en Valencia, los días 9 y 10 de diciembre de 2004 «B) Ejecuciones contra el patrimonio del deudor», y considera, respecto del art. 55.1.2. ${ }^{\circ}$, que corresponderá al Juez de lo Mercantil la decisión sobre si los bienes son o no necesarios para la continuidad de la actividad profesional o empresarial del concursado.

Especial situación de un embargo de la AEAT, sobre derechos de crédito de la entidad concursada, se resuelve por Auto del Juzgado de lo Mercantil n. ${ }^{\circ} 1$ de Málaga, de fecha 22 de julio de 2005, que alude a las diferentes connotaciones de las expresiones utilizadas por el legislador en los artículos 55 y 56 LC, así como a cuál es el órgano competente para determinar la necesidad del bien, en referencia a la Administración Pública o al Juzgado, siendo su parecer que corresponde al juez del concurso la determinación de 
la necesidad del bien a los efectos de las ejecuciones pendientes, partiendo de la universalidad del concurso (artículo 49 LC) y de que la norma en cuestión contiene una regla general de suspensión y varias excepcionales de continuidad en la ejecución. Considera bienes necesarios tanto bienes como derechos, partiendo de una clasificación en bienes necesarios de primer grado (los del inmovilizado) y de segundo grado (los del ciclo financiero), aunque declara que no es bien o derecho necesario para la continuidad de la actividad empresarial el embargo practicado por la administración tributaria respecto de los derechos de crédito que la concursada tiene respecto de otra sociedad, decisión que no resulta fácil de compartir, en general.

\subsubsection{ACCIÓN DIRECTA EX ARTículo 1597 DEL Código CiviL}

Dispone el artículo 1597 del CC: «Los que ponen su trabajo y materiales en una obra ajustada alzadamente por el contratista, no tienen acción contra el dueño de ella sino hasta la cantidad que éste adeude a aquél cuando se hace la reclamación».

Esta disposición puede incidir en los procesos concursales, particularmente en la suspensión de pagos y la quiebra, ahora en el concurso, del contratista.

Aunque pueda admitirse, con matices, de la doctrina científica ${ }^{27}$ y de los Tribunales de Justicia ${ }^{28}$, respecto del Derecho concursal derogado (Quiebras y Suspensiones de Pagos, principalmente), que el art. 1597 del C. civil ha querido dar a ciertos acreedores (Los que ponen su trabajo y materiales en una obra ajustada alzadamente por el contratista...) no ya un privilegio, sino un medio de satisfacción, considero más seguro que el nuevo concurso de acreedores ha vedado la agresión de terceros a la masa activa concursal (derecho de separación), así como cualquier acción sobre recuperación de créditos concursales, en general (derecho de ejecución separada).

\subsubsection{NUEVO CONCURSO DE ACREEDORES}

En la exposición de motivos de la Ley 22/2003, de 9 de julio, Concursal, se observa: «La Ley opta por los principios de unidad legal [texto único de Derecho material y procesal], de disciplina [comerciantes y no comerciantes] y de sistema [procedimiento único], así como ...la satisfacción de los acreedores..., finalidad esencial del concurso... Aunque el objeto del concur-

\footnotetext{
1969.

${ }^{27}$ Ángel YÁGÜEZ, R. de, Los créditos derivados del contrato de obra, Madrid, Tecnos,

${ }^{28}$ Entre otras, la STS (Sala de lo Civil), de fecha 9 de mayo de 1989; SAP de Pamplona, de fecha 1 de octubre de 2001; y Sentencia Audiencia Provincial de Barcelona (Sección 1.a), de 2 noviembre de 2004.
} 
so no sea el saneamiento de las empresas, un convenio de continuación puede ser instrumento para salvar las que se consideren parcial o totalmente viables...». Es destacable la proclamación de la unidad legal, que permite deducir que otras leyes no debieran interponerse o interferir en la finalidad del concurso.

La Sentencia del Juzgado de lo Mercantil n. ${ }^{\circ} 1$ de Madrid, de fecha 5 de julio de 2005, considera que la Ley Concursal no puede impedir la aplicación de la teoría general sobre la derogación tácita de las normas (artículo 2.2. C.C.) y que el inciso final del artículo 89.2 LC «no se admitirá en el concurso ningún privilegio o preferencia que no esté reconocido en esta Ley» es un mandato dirigido al intérprete con el fin de que adecue el sentido de eventuales normas extraconcursales relativas a privilegios crediticios concursales, a la letra y espíritu de la Ley Concursal, aunque la Ley Concursal no puede dejar sin efecto los principios rectores de nuestro ordenamiento jurídico relativos a la derogación tácita de las normas, sin embargo, el citado inciso impone un criterio que impide llevar a cabo una interpretación extensiva de las normas extraconcursales de las que se pudiera desprender algún privilegio no contemplado por la Ley Concursal.

Parece razonable que la acción directa del art. 1597 del C. civil puede considerarse de especial trascendencia para el patrimonio del deudor, como luego trataré de fundar al referirme a la masa activa, por lo que resulta de aplicación el art. 8 de la Ley concursal sobre competencia objetiva de los Juzgados de lo Mercantil.

En otro escenario, se pronuncia el citado Auto del Juzgado de lo Mercantil número uno de Las Palmas, de fecha 3 de enero de 2005, cuando declara que, para el buen fin del proceso concursal, resulta absolutamente indispensable que cualesquiera ejecuciones o apremios contra el deudor queden suspendidos e integrados en el concurso, pues, en otro caso, el seguimiento de ejecuciones separadas frustraría por completo la propia finalidad de obtener la par conditio creditorum a través del proceso concursal, es decir, la satisfacción y efectividad de los distintos créditos de modo proporcional y equitativo sin otra preferencia que aquella que la ley expresamente reconozca, cuestionando: ¿Cuál es el Órgano competente para decidir que los bienes objeto de embargo resultan o no necesarios para la continuidad de la actividad profesional o empresarial del deudor? Únicamente el Juez de lo Mercantil que conoce del proceso concursal puede valorar, a la vista de todas las circunstancias concurrentes, si un determinado bien o derecho resulta o no necesario para la continuidad de su actividad empresarial.

También, la exposición de motivos destaca: «La declaración de concurso, por sí sola, no interrumpe el ejercicio de la actividad profesional o empresarial del deudor...». Es decir, se establece el principio general de continuidad de las actividades del deudor, salvo que el Juez acuerde otra cosa, y cuya continuidad puede verse perjudicada si fuese aplicable la acción directa del art. 1597 del C. civil, en sede concursal. 


\subsection{Masa pasiva}

La exposición de motivos de la Ley 22/2003, de 9 de julio, Concursal, además de la atención que dedica a las acciones de ejecución de garantías reales sobre bienes del concursado, señala: «La ley regula asimismo con criterios de funcionalidad los efectos de la declaración de concurso sobre los acreedores, ordenando la paralización de las acciones individuales promovidas por éstos contra el patrimonio del concursado. Esta paralización, consecuencia natural de la integración de los acreedores en la masa pasiva del concurso, no afecta a las declarativas de los órdenes civil o social ya en tramitación en el momento de declararse el concurso, que continuarán hasta la firmeza de la sentencia, ni a las de naturaleza contencioso-administrativa o penal con trascendencia sobre el patrimonio del deudor, incluso si se ejercitan con posterioridad a la declaración, pero sí a todas las de carácter ejecutivo, incluidos los apremios administrativos o tributarios, que quedarán en suspenso si se hallasen en tramitación, salvo los acordados con anterioridad a la declaración de concurso, y no podrán iniciarse una vez declarado el concurso». Puede descartarse esta valoración, desde la realidad de que el subcontratista no ejerce acción alguna contra su deudor declarado en concurso, pues acciona con su derecho de crédito, un crédito distinto, contra el comitente, aunque el efecto conseguido es similar.

\subsection{Créditos concursales}

El artículo 49 dispone: «Declarado el concurso, todos los acreedores del deudor, ordinarios o no, cualesquiera que sean su nacionalidad y domicilio, quedarán de derecho integrados en la masa pasiva del concurso, sin más excepciones que las establecidas en las leyes». Precepto capital, que pone fin al derecho de ejecución separada, regulado en las leyes concursales derogadas, con algunas excepciones (ejecuciones administrativas y laborales, en su caso [art. 55], buques y aeronaves [art. 76.3], así como las contempladas en la disposición final decimoctava, que reforma la Ley de Mercado de Valores). Concordante con el art. 84.1: «Constituyen la masa pasiva los créditos contra el deudor común que conforme a esta Ley no tengan la consideración de créditos contra la masa».

El apartado 1 del art. 85, que expresamente cita el art. 21.1, ordena el llamamiento a los acreedores para que pongan en conocimiento de la administración concursal la existencia de sus créditos. La administración concursal realizará sin demora una comunicación individualizada a cada uno de los acreedores cuya identidad y domicilio consten en el concurso, informándoles de la declaración de éste y del deber de comunicar sus créditos, en la forma establecida en el artículo 85». No parece cuestionable que el derecho de crédito del subcontratista integra la masa pasiva del concurso. 


\subsection{Clasificación de créditos}

En la exposición de motivos, se observa: «La regulación de esta materia de clasificación de los créditos constituye una de las innovaciones más importantes que introduce la ley, porque reduce drásticamente los privilegios y preferencias a efectos del concurso, sin perjuicio de que puedan subsistir en ejecuciones singulares, por virtud de las tercerías de mejor derecho. Se considera que el principio de igualdad de tratamiento de los acreedores ha de constituir la regla general del concurso, y que sus excepciones han de ser muy contadas y siempre justificadas...».

$\mathrm{El}$ art. 89.1 establece las clases de créditos concursales y el inciso final del apartado 2 dispone: «No se admitirá en el concurso ningún privilegio o preferencia que no esté reconocido en esta Ley». Al parecer, el crédito del subcontratista, que pretenda ejercer la acción directa del art. 1597 del C. civil, por su naturaleza (Los que ponen su trabajo y materiales en una obra ajustada alzadamente por el contratista...), podría ser clasificado como refaccionario en el concurso del comitente (art. 90.3.'), pero nunca en el concurso del contratista.

La disposición final primera de la Ley concursal, sobre reforma del Código Civil, añade al artículo 1921 del Código Civil un párrafo segundo, con la siguiente redacción: «En caso de concurso, la clasificación y graduación de los créditos se regirá por lo establecido en la Ley Concursal». No parece descabellado considerar que la nueva redacción del art. 1921 del C. civil descarta la aplicación del art. 1597 en sede concursal, pues todos los créditos concursales quedan sometidos a las resultas del procedimiento universal. Aunque se admita la tesis de que el crédito del subcontratista no goza per se de privilegio alguno, lo cierto es que el art. 1597 del C. civil le reconoce un tratamiento distinto que a otros créditos concursales, distinción que puede calificarse de situación privilegiada.

\subsection{Masa activa}

El artículo 54 dispone, en caso de suspensión de las facultades de administración y disposición del deudor, que corresponderá a la administración concursal la legitimación para el ejercicio de las acciones de índole no personal, y, en caso de intervención, que el deudor conservará la capacidad para actuar en juicio, pero necesitará la conformidad de la administración concursal para interponer demandas o recursos que puedan afectar a su patrimonio. También previene que si la administración concursal estimare conveniente a los intereses del concurso la interposición de una demanda y el deudor se negare a formularla, el Juez del concurso podrá autorizar a aquélla para interponerla. El apartado 4 del art. 54 permite al acreedor ejercitar acciones de carácter patrimonial, cuando el concursado o la administración concursal no lo hiciesen, siempre que sean a su cargo los gastos procesales y, en su caso, la condena en costas. Representa, esta legitimación activa del acreedor, un paso decisivo sobre el derecho derogado, que ha mantenido a los acreedores «atados de pies y manos» para las reclamaciones patrimoniales del deudor frente a terce- 
ros, que fuesen aconsejables en interés del concurso y, por tanto, en su propio interés, por ser susceptibles de incrementar la masa activa. De lo expuesto puede interpretarse que la legitimación para el ejercicio de acciones de carácter patrimonial (demanda de cantidad contra el dueño de la obra) reside, especialmente, en la administración concursal o, por subrogación, aunque sólo en interés del concurso (no en interés propio), en los acreedores concursales, y no se pone en duda que el subcontratista ostenta un crédito concursal.

El artículo 71 regula la rescisión de los actos perjudiciales para la masa activa realizados por el deudor dentro de los dos años anteriores a la fecha de la declaración, aunque no hubiere existido intención fraudulenta, y establece la presunción absoluta, ente otros, cuando se trate actos de extinción de obligaciones cuyo vencimiento fuere posterior a la declaración del concurso, así como la presunción relativa, cuando se trate de actos dispositivos a título oneroso realizados a favor de alguna de las personas especialmente relacionadas con el concursado.

Los actos perjudiciales para la masa activa pueden haber sido realizados por acción u omisión del deudor. Si éste se hubiese «allanado» a la acción directa ejercida por su subcontratista contra el dueño de la obra, confabulándose con aquél para simular un vencimiento anterior de la obligación, cuando contractualmente fuese posterior a la declaración del concurso, podría prosperar la acción de reintegración. ¿Y si el subcontratista fuera persona especialmente relacionada con el concursado?

Las conjeturas expuestas pueden resaltar la incongruencia que representa la aplicación del art. 1597 en sede concursal.

El artículo 76 incorpora el principio de universalidad y, en consecuencia de la declaración de concurso, todos los bienes y derechos pertenecientes al deudor, conocidos o no, pasan automáticamente a integrar la masa activa, para la formación del inventario. Única excepción, en el art. 76.3, respecto de los titulares de créditos con privilegios sobre los buques y las aeronaves, aunque se les reconoce derecho de ejecución separada, no de separación.

Por último, el art. 80 regula el derecho de separación ex iure dominii, aunque no viene al caso.

De hecho y de derecho la acción del art. 1597 del C. civil supone una acción de separación de bienes (en este caso, de derechos) de la masa activa concursal, claramente prohibida en el nuevo concurso de acreedores.

\subsubsection{DOCTRINA}

Núñez-Lagos ${ }^{29}$ concluye: «... dado que la acción del art. 1597 Cc es directa e independiente, el crédito que con su ejercicio se reclama es el cré-

${ }^{29}$ NúÑEZ-Lagos Burguera, A., «¿Continúa pudiendo ejercitar el subcontratista la acción directa contra el comitente (ex artículo $1597 \mathrm{Cc}$ ) en el supuesto de concurso del contratista?» Revista de Derecho Concursal y paraconcursal, La Ley, Número 2/2005, pp. 327-331. 
dito del subcontratista contra el comitente, por lo que no puede haber conflicto ni derecho alguno del concurso a ese crédito... el crédito que nominalmente pudiera tener el concurso contra el comitente está estructuralmente condicionado o limitado (en virtud de la ley) al otro crédito que los subcontratistas pudieran tener o llegar a tener antes que el comitente deba pagar al deudor concursado, bajo el art. $1597 \mathrm{Cc} . »$.

No debo omitir la Sentencia del Juzgado de lo Mercantil n. 3 de Barcelona, de fecha 23 de mayo de 2005 , que pese a reconocer que se trata de una cuestión que suscita dudas de hecho y de derecho, estima las pretensiones de la parte demandante, al amparo del art. 1597 del C. civil, y reconoce el derecho del subcontratista a percibir la cantidad adeudada por el concursado con cargo a las cantidades consignadas por el comitente (dueño de la obra) en el Juzgado.

\subsubsection{RECAPITULACIÓN}

En mi modesta opinión, no es aplicable el art. 1597 del Código civil, promulgado en 1889, una vez declarado el concurso del contratista, regulado por la Ley de 2003, es decir, los que pusieron su trabajo y materiales en una obra ajustada alzadamente por el contratista no tienen acción contra el dueño de ella (el comitente), pues el derecho de crédito del subcontratista se integra en la masa pasiva concursal y la deuda del comitente (el dueño de la obra) constituye la masa activa del concurso.

La clasificación del crédito del subcontratista respetará las previsiones de los arts. 90 a 92, pudiendo ser subordinado, según las categorías de este último precepto, concordante con el art. 93.

En el supuesto de que el crédito del subcontratista, al que se refiere el citado art. 1597, fuese subordinado, es cuando quizá resulte más frustrante que pudiera ejercer la acción directa contra el comitente, aunque también si gozase de privilegio especial (garantía real -cuya ejecución se paraliza, según el art. 56-) o general (si hubiere instado el concurso necesario de su deudor, según el art. 91.6. ${ }^{\circ}$ ), en el concurso del contratista. Si se aceptase que el crédito del subcontratista goza de la garantía del comitente deudor ${ }^{30}$, convertido en deudor solidario con el contratista ${ }^{31}$, se paralizaría la acción directa (ejecución de la garantía real).

Para evitar el grave perjuicio que causaría retirar de la masa activa, por parte de un acreedor concursal, la deuda que el dueño de la obra tuviese con la concursada, y para cumplir diligentemente lo dispuesto en el art. 43 de la Ley concursal, sobre conservación y administración de dicha masa activa, la administración concursal podrá solicitar auxilio judicial y pedir al Juez del

\footnotetext{
${ }^{30}$ STS de 12 mayo 1994.

${ }^{31}$ STS de 22 diciembre 1999.
} 
concurso que requiera al comitente para que se abstenga de pagar a terceros sus deudas con el concursado y abone a este último sus derechos de crédito, directamente, a través de la administración concursal, o mediante consignación en cuentas del Juzgado de lo Mercantil.

\subsection{No compensación}

El art. 58 prohíbe la compensación de los créditos y deudas del concursado, sin perjuicio de lo previsto en el art. 205, salvo que los requisitos de la compensación (art. 1196 del Código Civil) hubieran existido con anterioridad a la declaración de concurso. El art. 164 de la Ley 58/2003, de 17 de diciembre, General Tributaria, sobre concurrencia de procedimientos, regula la compensación de créditos y deudas tributarias en los términos previstos en el art. 71 de la citada LGT. Es frecuente la convención sobre compensación de saldos en entidades de crédito.

El instituto de la compensación, regulado en los arts. 1195 a 1202 del Código Civil, entre el deudor concursado y un acreedor, ha sido discutido por la doctrina, hasta el punto de aceptarse, con matices, tan sólo en el supuesto de créditos y deudas nacidos de una misma relación jurídica. No es infrecuente que la entidad concursada sea deudora y simultáneamente acreedora de un tercero, a la fecha del auto de declaración de concurso. En principio, como norma general, se deberá reclamar al tercero lo que adeuda y el crédito de éste se integrará en la masa pasiva. Sin embargo, en la práctica se admite la compensación cuando se comprueba la existencia de cuenta corriente, de la que se deduce un saldo deudor o acreedor.

\subsection{Vigencia de los contratos con obligaciones recíprocas y resolución por incumplimiento}

El art. 61 se refiere a contratos celebrados por el deudor antes de su declaración en concurso. En el apartado 1 dispone, respecto de los contratos que, al momento de la declaración del concurso, una de las partes hubiera cumplido íntegramente sus obligaciones y la otra tuviese pendiente el cumplimiento total o parcial de las recíprocas a su cargo, que el crédito o la deuda correspondiente al deudor se incluirá, según proceda, en la masa activa o en la pasiva del concurso. El apartado 2 establece, como regla general, que la declaración de concurso no afecta a la vigencia de los contratos con obligaciones recíprocas pendientes de cumplimiento, tanto a cargo del concursado como de la otra parte, y que las prestaciones a que esté obligado el concursado tienen la consideración de deudas contra la masa, aunque con las siguientes excepciones: a) La declaración de concurso puede originar la ineficacia sobrevenida del contrato, siempre que así lo inste la administración concursal o el propio concursado; b) Incumplimiento imputable al concursado, posterior a la declaración de concurso (art. 1124 del C. Civil), pre- 
visto en el art. 62, que se dará siempre que sea de interés del concurso. Por último, el apartado 3 dispone que se tendrán por no puestas las cláusulas que establezcan la facultad de resolución o la extinción del contrato por la sola causa de la declaración de concurso de cualquiera de las partes.

Sirve de ayuda hermenéutica la Sentencia del Juzgado de lo Mercantil n. ${ }^{\circ} 1$ de Bilbao, de fecha 1 de septiembre de 2005, al matizar que la previsión del art. 62.1, cuando regula la «resolución por incumplimiento», se basa en el presupuesto fáctico que describe, es decir, contrato de obligaciones recíprocas que están pendientes por ambas partes, al declararse el concurso. La posibilidad del art. 62.1 es perfectamente razonable y trata de evitar que el crédito del acreedor siga incrementándose como consecuencia de la situación de concurso, cuando por su parte está obligado a terminar de cumplir su obligación contractual o continuar verificándolo, pese a que la concursada, que debe por su parte atender las suyas con cargo a la masa, no lo está haciendo.

Los contratos vigentes a la fecha de la declaración de concurso, según el art. 62, pueden resolverse con causa en su incumplimiento posterior por cualquiera de las partes, aunque el interés del concurso permite al juez acordar el cumplimiento del contrato, calificándose la prestación debida por el deudor como crédito contra la masa ${ }^{32}$.

Interesa la Sentencia del Juzgado de Primera Instancia n. ${ }^{\circ} 9$ de Córdoba y de lo Mercantil de la Provincia, de fecha 8 de julio de 2005, al plantear que la cuestión estriba en qué naturaleza tienen los créditos del acreedor cuyo contrato se mantiene por decisión judicial, pese al incumplimiento del concursado. En primer lugar, con el artículo 62.4, que con toda corrección conceptual distingue entre las obligaciones procedentes de incumplimiento anterior a la declaración del concurso, que se incluirán como créditos concursales, y las dimanantes de incumplimiento posterior, que se satisfarán con cargo a la masa. Y, en segundo término, con el artículo 84, que al enumerar los créditos contra la masa, no incluye los créditos anteriores a la declaración de concurso generados por el incumplimiento de contratos de tracto sucesivo, pues, de lo contrario, los acreedores cuyo crédito procede de un contrato de tracto sucesivo verían mejorada su posición, mediante la conversión de todos sus créditos en créditos contra la masa y por tanto abonables inmediatamente (artículo 154), mediante el simple expediente de ejercitar la acción prevista en el artículo 62.1 de la propia Ley, con un resultado absurdo, desigualitario y conculcador del principio de par conditio creditorum, que no puede ser admisible.

En la misma dirección, la Sentencia del Juzgado de lo Mercantil n. ${ }^{\circ}$ 2, de Barcelona, de fecha 21 de julio de 2005, que ordena el cumplimiento del

${ }^{32}$ Sentencia del Juzgado de lo Mercantil n. ${ }^{\circ} 1$ de Madrid, de fecha 15.04.2005; Sentencia del Juzgado Mercantil n. ${ }^{\circ} 2$ de Barcelona, de fecha 21.07.2005; y, Sentencia del Juzgado Mercantil de Santander, de fecha 29.10.2005. 
contrato de suministro de energía eléctrica suscrito entre las partes, el día 10 de septiembre de 2004, y que se abonen con cargo a la masa las prestaciones que haya de satisfacer la concursada, así como que el crédito anterior a la declaración de concurso, por importe de 154.779,67 euros, deberá ser calificado como concursal y ordinario.

De igual modo, resuelve el Juzgado de lo Mercantil n. ${ }^{\circ} 1$ de Madrid, en sentencia de fecha 15 de abril de 2005, con costas a la parte demandante, y declara no haber lugar a la resolución contractual solicitada, con las consecuencias que ello conlleva para la entidad concursada, en relación con el pago de los suministros efectuados con posterioridad a la declaración del concurso, y sin perjuicio de que el crédito a favor de la actora haya sido incluido en la lista de acreedores por los cauces previstos en la Ley concursal. Las costas se imponen a la entidad demandante.

Sin embargo, el Juzgado de lo Mercantil n. ${ }^{\circ} 1$ de Valencia, en la Sentencia de fecha 14 de julio de 2005, resuelve a favor de la compañía eléctrica y considera que las deudas anteriores a la declaración del concurso deben ser satisfechas con cargo a la masa, es decir, como créditos contra la masa.

En la Sentencia del Juzgado de Primera Instancia n. ${ }^{\circ} 10$ (Mercantil) de Santander, de fecha 19 de octubre de 2005, se desestima la demanda incidental interpuesta por la compañía eléctrica, con costas, y considera que, cuando de contratos de tracto sucesivo se trata, el simple impago de los recibos adeudados no implica por sí solo la concurrencia de causa de resolución del contrato sino que es procedente que, junto a dicho incumplimiento, se aprecien circunstancias que impidan catalogarlo como un mero retraso y concluye que se trata de un retraso que no constituye un incumplimiento relevante a efectos de la resolución del contrato, por lo que desestima la acción de resolución ejercitada, y en cuanto a la petición subsidiaria, de que se acuerde la calificación como crédito contra la masa los recibos impagados, no accede a ella, si bien tal calificación habría de concederse en el supuesto de que se apreciase la concurrencia de causa de resolución y a que, a pesar de ello, se acordase el cumplimiento del contrato. En el supuesto planteado, al no estimarse que concurra causa de resolución, la situación del crédito de la actora no resulta modificada, por lo que ha de calificarse como crédito ordinario en cuanto a las cuotas por no estar prevista ninguna calificación especial.

\subsection{Contratos de trabajo}

Sobre suspensión de relaciones laborales, regulada en el art. 64, el Auto del Juzgado Mercantil n. ${ }^{\circ} 1$ de Málaga, de fecha 29 de marzo de 2005, considera que es necesario, en primer lugar, adecuar la situación actual a la legalidad en protección de los trabajadores y, derivado de ello, de la propia empresa y, por tanto, proceder a la suspensión temporal colectiva de las relaciones laborales de todos los trabajadores de la empresa reconocidos en el 
informe de la administración concursal. La medida colectiva insinuada por los representantes de los trabajadores es evidente, pues la puesta en marcha del centro de trabajo requerirá personal para atender las necesidades de la empresa. Optar por la extinción supondría que lo único que se hace, respecto de la empresa, es vulnerar los derechos adquiridos de los trabajadores pasando por convertir el expediente de regulación de empleo en un método fácil y barato de extinción de los puestos de trabajo, pues posteriormente necesitarían nuevos trabajadores, respecto de los cuales las condiciones podrían variar y dicha medida es conforme al artículo 47 del Estatuto de los Trabajadores, visto lo fundamentado y la situación coyuntural económica de la entidad concursada.

Por Auto del Juzgado de lo Mercantil n. ${ }^{\circ} 1$ de Cádiz, de fecha 15 de abril de 2005 , se admite a trámite la solicitud formulada por los administradores concursales de iniciar expediente de suspension colectiva de relaciones laborales, en las que resulta empleador el concursado, aunque la solicitud se presentó cuando todavía no se había emitido el informe de la administración concursal, habiéndose alegado y razonado que la demora en la aplicación de las medidas podría comprometer la viabilidad futura de la empresa, cosa que admite el artículo 64 de la LC, y que la otra alternativa supondría la extinción de los contratos de trabajo por falta de pago de salarios (art. 50.1 b ET), lo que provocaría que la indemnización a abonar se calificarse como crédito contra la masa (art. $84 \mathrm{LC}$ ), aumentando el endeudamiento de la concursada y sin posibilidad de reincorporación de los trabajadores.

Sobre extinción, el Auto del Juzgado de lo Mercantil n. ${ }^{\circ} 4$ de Madrid, de fecha de 27 enero de 2005, autoriza la extinción colectiva de relaciones laborales, en los términos convenidos, de una parte de la plantilla, como medida que resulta imprescindible para equilibrar la situación económico-financiera de la empresa y garantizar su futura viabilidad, evitando el mal mayor que supondría la destrucción de la totalidad de sus puestos de trabajo, pues tal medida se integra dentro de un programa que prevé tanto la reestructuración del patrimonio empresarial (lo que supondrá la enajenación de activos y la adquisición de inmuebles de dimensión más adecuada a su actividad futura) como la selección de determinadas líneas de actividad negocial, prescindiendo de las que no estaban resultando rentables, lo que justifica la decisión de reducir personal y con ello ahorrarse importantes costes para el futuro, y cuya situación apunta a la existencia de causas económicas, técnicas, organizativas o de producción que están previstas en la Ley como motivos para fundar la extinción colectiva de contratos laborales (artículo 51 del Estatuto de los Trabajadores).

Sobre extinción, el Auto del Juzgado de lo Mercantil n. ${ }^{\circ} 1$ de Bilbao, de fecha 3 de marzo de 2005, acuerda la extinción solicitada por los trabajadores, pese a que la autoridad laboral sostiene que la solicitud de los cinco trabajadores no supone despido colectivo, al amparo de lo dispuesto en el art. 51.1 del ET, porque no se alcanza el número que dispone tal norma, es decir, al menos seis trabajadores, y que, por aplicación de los arts. 6.2 y 64.1 de la 
LC, no nos encontramos ante un «despido colectivo». Funda la decisión en que la LC tiene unas reglas específicas en otros apartados, que por ser especiales y propias de una situación concursal preponderan sobre las generales del ET. En efecto, a diferencia de lo dispuesto en el art. 51.1 del ET, que considera despido colectivo la extinción de los contratos de trabajo que afecten a la totalidad de la plantilla de la empresa, siempre que el número de trabajadores afectados sea superior a cinco, cuando aquél se produzca como consecuencia de la cesación total de su actividad empresarial, el párrafo segundo del art. 67.10 de la LC dice expresamente que «se entenderá en todo caso que son colectivas las acciones ejercidas por la totalidad de la plantilla de la empresa». No exige, por lo tanto, la LC que, además de afectar a la plantilla completa, el despido tenga que afectar a más de cinco trabajadores.

El Juzgado de lo Mercantil n. ${ }^{\circ} 1$ de Valencia, por Auto de fecha 28 de julio de 2005, aprueba la solicitud de expediente de regulación de empleo para la extinción colectiva de los contratos de trabajo de los trabajadores de los que es empleador el concursado, de parte de la plantilla laboral, a instancias de la deudora concursada, con la aquiescencia de la Administración concursal, en atención a que la solicitud se deduce después de la declaración de concurso, y siendo trascendente al buen fin del concurso no haber de esperar al informe de la Administración ex artículo 75 LC, haciéndose recurso en este sentido del supuesto que autoriza el artículo 64.3 de la LC, en la consideración de que su posposición a tal momento cronológico podría comprometer la virtualidad de la eficacia de las medidas colectivas que se trataban de adoptar, no habiéndose alcanzado acuerdo en el periodo de consultas entre la administración concursal y los representantes de los trabajadores, acordándose respecto de éstos y en tal consideración una indemnización de treinta días de salario por año de servicio con límite de dieciocho mensualidades.

Guarda relación con los expedientes de extinción de relaciones laborales, aunque resuelve sobre una solicitud de acumulación al proceso concursal de acciones individuales por parte de trabajadores, el mencionado Auto del Juzgado de lo Mercantil n. 1 de Madrid, de fecha 27 de mayo de 2005, que desestima la solicitud formulada por la administración concursal, porque en ningún caso cabría integrar en un hipotético expediente de regulación de empleo los procedimientos en que se hayan ejercitado acciones individuales de resolución de contratos laborales, al amparo de lo previsto en el artículo 50.1, letra b ET, que hayan finalizado por Sentencia dictada por el Juzgado de lo Social.

\subsection{Acumulación de juicios de desahucio}

La posibilidad de rehabilitación de $\operatorname{contratos}^{33}$ de préstamo y demás de crédito ex art. 68 requiere conocimientos financieros de oportunidad y el

${ }^{33}$ Martínez SANZ, F., «Efectos del concurso sobre los contratos mercantiles pendientes», Noticias Jurídicas, Bosch on-line, febrero 2004. 
estudio de las previsiones de tesorería que permitan comprometerse en el cumplimiento de las prestaciones futuras, al igual que la decisión de rehabilitar los contratos de adquisición de bienes muebles o inmuebles con contraprestación o precio aplazado, prevista en el art. 69, así como la iniciativa de enervar la acción de desahucio ejercitada contra el deudor, con anterioridad a la declaración del concurso, o de rehabilitar la vigencia del contrato hasta el momento mismo de practicarse el efectivo lanzamiento ex art. 70.

No parece posible la acumulación de los procesos de ejecución a que pueden dar lugar las sentencias de desahucio, según la Sentencia del Juzgado de lo Mercantil n. ${ }^{\circ} 2$ de Madrid, de fecha 30 de noviembre de 2004, que resuelve no ha lugar a acordar la acumulación pretendida por la entidad concursada, pues en la ejecución de una sentencia de desahucio no se tiende a la efectividad de derecho de crédito alguno.

Sin embargo, el Auto del Juzgado de lo Mercantil n. ${ }^{\circ} 1$ de Málaga, de fecha 24 de abril de 2006, decide exhortar al juzgado de Primera Instancia correspondiente, para que en el procedimiento de desahucio que ordena el lanzamiento acuerde, en protección de la masa activa del concurso, las medidas solicitadas por la administración concursal y que nombre depositario en la persona del arrendador desahuciante de los bienes que no sean objeto del título con las obligaciones inherentes a dicho cargo, así como que fije en ejecución de sentencia, a instancia de la administración concursal, la obligación de abono del valor de los bienes y derechos no separables que forman parte de la masa activa, con cargo al arrendador, nombrando igualmente depositario de éstas.

\subsection{Ejercicio de acciones rescisorias de actos perjudiciales para la masa activa}

El artículo 71 dispone: «1. Declarado el concurso, serán rescindibles los actos perjudiciales para la masa activa realizados por el deudor dentro de los dos años anteriores a la fecha de la declaración, aunque no hubiere existido intención fraudulenta...». Se presume perjuicio iuris tantum: a) donaciones; b) actos de disposición a título gratuito, salvo las liberalidades de uso, en general, donaciones; iuris et de iure: c) constitución de garantías reales a favor de obligaciones preexistentes; $y, d$ ) transmisiones a favor de personas especialmente relacionadas con el deudor (art. 93), es decir, favorecimiento de acreedores (arts. 71 a 73).

Puede afectar a negocios válidos, que se declaran ineficaces, y que refuerza otras acciones de rescisión civil (arts. 1290 a 1299 del C. civil).

Sobre la aplicación del citado art. 71.1, se pronuncia la Sentencia del Juzgado de lo Mercantil n. ${ }^{\circ} 2$ de Barcelona, de fecha 25 de febrero de 2005, que acuerda la rescisión del contrato de «adjudicación en pago de deuda», mediante el cual el deudor transmitió determinadas parcelas de terreno, apenas dos meses antes de la declaración del concurso, en pago de una deuda 
preexistente, por alterar, en perjuicio del resto de los acreedores, el principio de la paridad o la llamada par conditio creditorum, así como porque la adjudicación de parcelas en pago de deudas no integra la actividad ordinaria de la demandada, que se dedica a la promoción de viviendas.

En relación con el citado art. 71.2 y 3.2. ${ }^{\circ}$, sobre favorecimiento de acreedores y constitución de hipoteca para garantizar una obligación preexistente, se pronuncia la Sentencia del Juzgado de lo Mercantil n. ${ }^{\circ} 2$ de Barcelona, de fecha 25 de febrero de 2005, que acuerda la rescisión de la constitución de hipoteca, apenas dos meses antes de la declaración del concurso, en garantía de una deuda preexistente de la concursada con tercero, pues constituye un acto que debe presumirse perjudicial para la masa activa, debido a que no nos hallamos ante un pago corriente realizado en el ejercicio de la actividad ordinaria del deudor, sino ante un acto rescindible directamente relacionado con la previa constitución de una hipoteca para garantizar una obligación preexistente, dada la evidente alteración del principio de la paridad o la par conditio creditorum en perjuicio del resto de acreedores.

El art. 71.3 dispone: «Salvo prueba en contrario, el perjuicio patrimonial se presume cuando se trate de los siguientes actos: $1^{\circ}{ }^{\circ}$ ) Los dispositivos a título oneroso realizados a favor de alguna de las personas especialmente relacionadas con el concursado...».

Sobre el particular se pronuncia la Sentencia del Juzgado de Primera Instancia . $^{\circ} 9$ de Córdoba y de lo Mercantil de la Provincia, de fecha 25 de julio de 2005, que acuerda la rescisión de un contrato de dación de bienes en pago de deudas y de los contratos de arrendamiento de los bienes cedidos al cedente, por considerarlos perjudiciales para la masa, además de haberse celebrado con persona especialmente relacionada con el concursado.

Sigue el art. 71.3: «Salvo prueba en contrario, el perjuicio patrimonial se presume cuando se trate de los siguientes actos:... 2. ${ }^{\circ}$ ) La constitución de garantías reales a favor de obligaciones preexistentes o de las nuevas contraídas en sustitución de aquéllas».

Respecto de la constitución de garantías reales a favor de obligaciones preexistentes, la Sentencia del Juzgado de lo Mercantil n. ${ }^{\circ} 1$ de Bilbao, de fecha 9 de septiembre de 2005, resuelve la rescisión de la garantía pignoraticia sobre unas vacas (prenda sin desplazamiento) y la modificación de la calificación del crédito del Banco Urquijo S. A., de privilegio especial a ordinario, con causa en que ha sucedido lo que el legislador previene en el art. 71 de la Ley concursal, esto es, que un acreedor obtiene, dentro del periodo sospechoso, una garantía añadida sobre una deuda aparentemente nueva, pero que en realidad es anterior, mejorando de forma obvia su condición y posición frente a los demás acreedores de la concursada, lo que permite aplicar la previsión del art. 71.3.2. ${ }^{\circ}$ de la Ley concursal, pues se han constituido garantías reales a favor de obligaciones preexistentes, o nuevas contraídas en sustitución de aquéllas, y el perjuicio patrimonial se presume, salvo prueba en contrario (art. 71.3), puesto que lo que ha sucedido es que pocos meses 
antes de la declaración de concurso, cuando una de las empresas del grupo entra en suspensión de pagos, el Banco Urquijo S. A. logra situarse en una situación ventajosa respecto del resto de acreedores.

\section{Informe de la administración concursal ${ }^{34}$}

\subsection{Comunicación de créditos}

El apartado 1 del art. 85 es concordante con lo dispuesto en el art. 21.1, que expresamente cita, sobre llamamiento a los acreedores para que pongan en conocimiento de la administración concursal la existencia de sus créditos, en el plazo de un mes a contar desde la última de las publicaciones acordadas en el auto, y con el art. 21.4, que ordena a la administración concursal que realice sin demora una comunicación individualizada a cada uno de los acreedores cuya identidad y domicilio consten en el concurso, informándoles de la declaración de éste y del deber de comunicar sus créditos. Recuerdo esta obligación de información a los acreedores conocidos que tengan su residencia habitual, su domicilio o su sede en los demás Estados miembros de la Unión Europea, según el mencionado art. 40 del Reglamento Comunitario, de obligado cumplimiento desde el 31.05.2002, así como lo dispuesto en el art. 214 de la Ley concursal, que impone el deber a la administración concursal de informar sin demora a los acreedores conocidos, que tengan su residencia habitual, domicilio o sede en el extranjero, de que ha sido declarado en concurso su deudor. Llamo la atención que el plazo para insinuar sus créditos por estos acreedores «extranjeros» (un mes) se computará desde la fecha que reciban la nota o escrito de la administración concursal. Conviene recordar que en procedimiento abreviado el plazo establecido será de quince días (arts. 190 y 191).

En la Primera Mesa Redonda ${ }^{35}$ del II Congreso de Derecho Mercantil, celebrado en Valencia, los días 1 y 2 de diciembre de 2005, sobre «Aspectos jurídicos de la formación de la lista de acreedores», se abordan las siguientes cuestiones:

«a) ¿Deben los administradores aportar los resguardos o documentos acreditativos de haber efectuado las comunicaciones previstas en el artículo 21.4? Parece que no es preceptivo que los administradores aporten los documentos $\mathrm{u}$ otros medios acreditativos de esas comunicaciones para la continuación del procedimiento.

34 Gómez Martín, F., «La Administración concursal», Revista Estudios de Deusto, Publicaciones de la Universidad de Deusto, Vol. 50/2 Julio-Diciembre 2002.

${ }^{35}$ Relator: Antoni Frigola, Magistrado, Juzgado de lo Mercantil n. ${ }^{\circ} 1$ de Madrid. Intervinientes: Enrique García García, Magistrado, Juzgado de lo Mercantil n. ${ }^{\circ} 4$ de Madrid y Rafael Fuentes Devesa, Magistrado, Juzgado de lo Mercantil de Alicante. 
b) ¿Cuál es la sanción por su no aportación? Ninguna, aunque si el deber de realizar las comunicaciones individuales se incumple por los administradores concursales, ello pueda ser considerado justa causa para su separación (art. 37) y, en su caso, generadora de responsabilidad, si es causante de daños (artículo 36).

c) ¿Son gastos de la masa [los de las comunicaciones previstas en el artículo 21.4] o se entienden incluidos en su remuneración? Descartada su integración en la retribución por aranceles, habrá que entender que el importe de los gastos derivados de esas comunicaciones deben considerarse créditos contra la masa, bien por su catalogación como gastos judiciales ocasionados o inherentes a la declaración del concurso (artículo 84.2.2..$^{\circ}$, bien por resultar de obligaciones válidamente contraídas durante el procedimiento por la administración concursal (artículo 84.2.10. ${ }^{\circ}$ ).

d) ¿Qué ocurre cuando la empresa concursada está cerrada y no tiene tesorería alguna? ¿Quién atiende esos gastos de comunicaciones? Una primera aproximación es que puede llevarse a cabo la comunicación por la oficina judicial, aunque no lo prevé la Ley. Me parece más seguro que debe anticiparse el gasto por la administración concursal, como «gajes» del oficio».

\subsection{Plazo para la presentación del informe de la administración concursal}

El plazo para la presentación del informe de la administración concursal será de dos meses, contados a partir de la fecha en que se produzca la aceptación de dos de ellos, según el art. 75. Sin embargo, dado que este plazo puede colisionar con el de un mes que los acreedores disponen para la comunicación de sus créditos, a contar desde la última de las publicaciones acordadas en el auto de declaración de concurso (art. 85 en relación con el 211.5. ${ }^{\circ}$ ), el Juzgado de lo Mercantil n. ${ }^{\circ} 1$ de Bilbao, en Auto de fecha 29 de abril de 2005, considera prudente y razonable que el término para la emisión del informe, por parte de la administración concursal, se inicie desde la última de las publicaciones y no desde la aceptación de dos de ellos o del único en el caso del procedimiento abreviado.

En la Primera Mesa Redonda del II Congreso de Derecho Mercantil, celebrado en Valencia, los días 1 y 2 de diciembre de 2005, sobre «Aspectos jurídicos de la formación de la lista de acreedores», se aborda esta cuestión:

«En el caso en que el plazo para la emisión del informe de la Administración concursal finalice antes que el plazo concedido a los acreedores para la comunicación de créditos previsto en el artículo 85 LC, ¿cuál es la mejor forma de actuar por parte del Juez del Concurso? 1) Que la Administración concursal solicite prórroga para la presentación del informe y la documentación complementaria, por entender que se encuentra ante una situación extraordinaria (artículo 74.1 LC). 2) Si la Administración concursal ya ha presentado el informe, tenerlo por presentado, aunque manteniendo sin publicar tal presentación, y esperar el transcurso del plazo del 
mes desde la última de las publicaciones del edicto declarando el concurso, y una vez finalizado el mismo acordar que la Administración concursal presente una nueva lista completando la anterior, verificado lo cual se procederá a publicar, según lo previsto en el artículo 95.2 LC».

Así se observa en el Auto del Juzgado de lo Mercantil n. ${ }^{\circ} 2$ de Bilbao, de fecha 21 de abril de 2006, que acuerda que el informe del art. 74 LC tiene que presentarse a la terminación del plazo legal, a fin de no incurrir en sanción de pérdida de retribución, sin perjuicio de que la presentación extemporánea de un texto complementario de la lista de acreedores, por cuanto accedan al Juzgado comunicaciones posteriores, dentro o fuera del plazo legal por retardo de las publicaciones oficiales, no dejará de ser eficaz y plenamente conducente a excluir impugnaciones innecesarias, debiendo advertirlo la administración concursal si le consta esa eventualidad, a fin de que se retenga la exposición del informe incompleto en la Secretaría.

El mismo Juzgado de lo Mercantil, en Providencia de la misma fecha, resuelve: «1. La anterior ampliación del informe de la administración concursal y sus documentos, respecto del inventario de bienes y derechos, únase a los autos de su razón. 2. Comuníquese la presentación de esta ampliación del informe a las partes personadas, haciéndoles saber que pueden examinar el informe y los documentos complementarios en la Secretaría del Juzgado. 3. Anúnciese la presentación de la misma por medio de edictos que se fijarán en el tablón de anuncios del Juzgado. 4. Hágase saber a los interesados que se abre el plazo de diez días, para impugnar los textos del Informe, en su última versión, a contar desde la publicación en el tablón de anuncios».

\subsection{Ausencia de documentos para informar}

En el concurso necesario, en el auto de declaración se requerirá al deudor para que presente los documentos enumerados en el art. 6 (art. 21.1.3. ${ }^{\circ}$. Si no lo hiciere, se presume dolo o culpa grave del deudor, en la generación o agravación del estado de insolvencia, salvo prueba en contrario (art. 165.2), que puede dar lugar a que se califique el concurso como culpable.

Cuando el deudor no hubiese cumplido el requerimiento de entrega al Juzgado de la documentación prevista en el citado art. 6, ¿qué respuesta habría de dar la administración concursal, en su informe ex art. 75.1.1. ${ }^{\circ}$, al ordinal 2..$^{\circ}$ del apartado 2 del art. 6, es decir, a la memoria? Una primera lectura permitiría una opinión negativa, es decir, nada que analizar y nada que informar. Sin embargo, considero aconsejable, ante la ausencia de la memoria requerida, que la administración concursal hiciese el esfuerzo de indagar sobre los datos a incluir en la citada memoria e informar de los que disponga. 


\subsection{Masa activa}

Como consecuencia de la declaración de concurso, todos los bienes y derechos integrados en el patrimonio del deudor, conocidos o no, pasan automáticamente a constituir la masa activa, así como los que se reintegren o adquiera hasta la conclusión del procedimiento (art. 76.1). Es decir, se incorpora a la masa activa el inventario y aquellos bienes o derechos que procedan de las acciones de reintegración, mediante rescisión de actos perjudiciales para la masa activa, realizados por el deudor dentro de los dos años anteriores a la declaración de concurso. También pueden formar parte de la masa activa los bienes procedentes de la rehabilitación de contratos de préstamo y demás de crédito ex art. 68, al igual que los resultantes de la decisión de rehabilitar los contratos de adquisición de bienes muebles o inmuebles con contraprestación o precio aplazado, prevista en el art. 69, así como consecuencia de enervar la acción de desahucio ejercitada contra el deudor, con anterioridad a la declaración del concurso, o de rehabilitar la vigencia del contrato de arrendamiento (derechos de traspaso), hasta el momento mismo de practicarse el efectivo lanzamiento, según art. 70.

\subsubsection{INVENTARIO}

La mención «La administración concursal elaborará a la mayor brevedad posible un inventario...», en el art. 82.1, incorporada por enmienda parlamentaria, aunque indeterminada, puede justificarse en consideración a la utilidad que proporcione su conocimiento a los propios administradores concursales, dando por supuesto que el deudor está debidamente informado sobre la composición de su masa activa, a los fines de conservación o realización, según convenga. El inventario de la masa activa es un documento que se unirá al informe ex art. 75.2.1. ${ }^{\circ} \mathrm{y}$, para su presentación, los administradores concursales disponen del plazo de dos meses desde su aceptación, prorrogable por un mes más, salvo en procedimiento abreviado, donde el plazo es de un mes prorrogable por quince días. No parece factible, en general, que el inventario elaborado por la administración concursal pueda cerrarse el día anterior al de la emisión de su informe, sobre todo si se encuentra con una empresa mercantil o profesional que ha continuado sus actividades, a no ser que una fecha sea la de emisión del informe y otra, posterior, la de su presentación al Juzgado.

\subsubsection{Saldos deudores de la HaCienda PÚBLICA}

Sobre el tratamiento del IVA soportado y de las retenciones a cuenta de los impuestos personales sobre la renta, a efectos de su integración en la masa activa, se pronuncia la Sentencia del Juzgado de lo Mercantil n. ${ }^{\circ} 1$ de Oviedo, de fecha 1 de marzo de 2005, y desestima la inclusión de IVA soportado, pues la posible obligación de devolución por la Hacienda Pública nace 
al 31 de diciembre de cada año, así como la de la partida «Hacienda Pública, Retenciones y Pagos a Cuenta», puesto que en ningún caso es posible que el pretendido derecho de crédito a favor de la concursada pueda nacer con anterioridad a la expiración del correspondiente periodo impositivo.

\subsubsection{GRAVÁMENES, TRABAS Y CARGAS}

En relación con el art. 82.2 y 3, sobre trabas y embargos que afecten a los bienes o derechos inventariados, conviene recordar: a) la Ley 58/2003, de 17 de diciembre, General Tributaria (art. 131.5); y b) el Texto Refundido de la Ley General de la Seguridad Social, aprobado por Real Decreto Ley 1/1994, de 20 de junio (art. 37).

Interesa, al respecto, la Sentencia del Juzgado de Primera Instancia n. ${ }^{\circ}$ 10 y de lo Mercantil de Santander, de fecha 29 de junio de 2005, la cual resuelve, de conformidad con lo establecido en el artículo 82.3, que no procede tener en cuenta en el avalúo de la masa activa los embargos, interpretando que dicho precepto únicamente establece que serán tenidos en cuenta en el avalúo en aquellos casos en que las deudas no estén incluidas en la masa pasiva, lo cual resulta lógico puesto que si se incluyen en la masa pasiva y además se tuviesen en cuenta en el avalúo de los bienes embargados, se estaría computando dos veces el mismo crédito, por un lado sumándolo al total de la masa pasiva y, por otro, deduciendo el valor de la masa activa, lo que daría lugar a que dichos documentos no reflejasen la verdadera situación de activo y pasivo.

\subsection{Masa pasiva}

A la solicitud de declaración de concurso acompañará el deudor, entre otros documentos, la relación de acreedores por orden alfabético, con expresión de la identidad de cada uno de ellos, así como de la cuantía y el vencimiento de los respectivos créditos y las garantías personales o reales constituidas. Si algún acreedor hubiera reclamado judicialmente el pago, se identificará el procedimiento correspondiente y se indicará el estado de las actuaciones (art. 6.2.4. ${ }^{\circ}$ ). Creo que no se han considerado posibles procedimientos administrativos de apremio en curso, cuyo conocimiento también hubiese sido relevante. Si no acompañare alguno de los documentos mencionados en el referido artículo, el deudor deberá expresar la causa (art. 6.5). Los apartados 2, 3 y 4 del mentado art. 6 pueden relacionarse con el art. 13.2, sobre la posible justificación o subsanación de defectos que adoleciere la solicitud de concurso voluntario, que faculta al Juez para declarar no haber lugar a su admisión, cuando no se justifique o subsane lo señalado al solicitante. En el concurso necesario, el deudor será requerido para que presente los documentos enumerados en el art. 6 (art. 21.1.3.'), aunque su incumplimiento no suspenderá la tramitación del procedimiento ni permitirá su sobre- 
seimiento, pero puede ser causa de calificación de concurso culpable (art. 165.2..$^{\circ}$.

\subsubsection{FECHA DE REFERENCIA DE LA LISTA DE ACREEDORES}

Dispone el art. 94: «Al informe de la administración concursal se acompañará la lista de acreedores, referida a la fecha de solicitud del concurso...». Dada la contradicción del texto «... a la fecha de solicitud del concurso» con lo establecido en el art. 49, que ordena la integración de todos los acreedores en la masa pasiva, una vez declarado el concurso, las resoluciones de los Juzgados de lo Mercantil n. ${ }^{\circ} 1$ Vitoria-Gasteiz, de fecha 21 de junio de 2005 , y de Málaga, de fecha 18 de julio de 2005, han interpretado que dicha lista de acreedores debe referirse a la fecha de declaración del concurso.

\subsubsection{CONTENIDO DE LA LISTA DE ACREEDORES}

Conviene recordar el art. 86.1, sobre facultades de la administración concursal relativas a la adopción de decisiones para reconocimiento o exclusión de créditos, que en el apartado 1 del art. 94 se plasma la lista de acreedores, compuesta de dos relaciones: una de los créditos incluidos (reconocidos) y otra de los excluidos (no reconocidos).

\subsubsection{RETRIBUCIÓN DE LOS ADMINISTRADORES CONCURSALES}

No procede incluir la retribución de la administración concursal en la lista de acreedores, pues son créditos a cargo de la masa o contra la masa (art. 34), como señala el Auto del Juzgado de lo Mercantil de La Coruña, de fecha 7 de enero de 2005, debiendo figurar en la relación de créditos contra la masa ex art. 94.4, en su caso.

El apartado 5 del artículo 4 del RD 1860/2004, que aprueba el arancel sobre derechos de los administradores concursales, establece: «En el caso de que el juez hubiera ordenado la tramitación abreviada del concurso, la cantidad que resulte por aplicación de lo establecido en este artículo se incrementará entre un 5 por ciento y un 25 por ciento, si la administración concursal estuviera integrada por un único miembro»; y, el art. 5 dispone: «1. La cantidad que resulte por aplicación de lo establecido en el artículo anterior se reducirá un 25 por ciento, cuando se hubiera cesado o suspendido o cuando cese o se suspenda la actividad profesional o empresarial que viniera ejerciendo el deudor. 2. $\mathrm{Si}$ el cese o la suspensión fueran parciales, el juez determinará a su prudente arbitrio el porcentaje de la reducción». Se observa que el incremento es facultad discrecional del Juez del concurso (entre un 5 y un 25\%) y la reducción imperativa $(25 \%)$, si el cese fuera total, que supone menor retribución cuanto mayor sea el incremento, aunque es de esperar que los Magistrados de lo Mercantil interpreten razonablemente la desacertada literalidad reglamentaria. 
En el estudio de la retribución de los administradores concursales, no puede silenciarse la decepción sufrida por las profesiones llamadas al ejercicio de este cargo, cuando conocieron el referido arancel y las exiguas cantidades resultantes de su aplicación, en la mayoría de los concursos con masas activas y pasivas de escasa cuantía, sin que se hubiesen atendido las fundadas recomendaciones sobre el establecimiento de un mínimo decoroso.

\subsubsection{PERIODIFICACIÓN DE CRÉDITOS POR RETENCIONES DE IRPF Y PARA LA $T_{G S S^{36}}$}

En relación con las nóminas, si se encontrasen a medio camino para su liquidación, por no haber finalizado el mes correspondiente, cuando se inicie el procedimiento de concurso (auto de declaración), no habría llegado el momento de practicar retención alguna, a cuenta del IRPF (arts. 1, 2.1, 6.1, 16.1, 101.1 y 107.1 del Real Decreto Legislativo 3/2004, de 5 de marzo, por el que se aprueba el texto refundido de la Ley del Impuesto sobre la Renta de las Personas Físicas, y Real Decreto 1775/2004, de 30 de julio, por el que se aprueba el Reglamento del Impuesto sobre la Renta de las Personas Físicas), que tendrá lugar en la fecha de pago, o para cotizar a la Seguridad Social (art. 104), cuya liquidación también se practicará cuando nazca la obligación salarial, es decir, al finalizar el mes correspondiente, luego no cabe plantear provisión de ninguna clase y menos aún calcular ambas retenciones sobre parte de las nóminas, para su inclusión en la lista de acreedores, pues a la fecha de la declaración de concurso, salvo que coincidiese con el último día de mes, no han nacido como créditos concursales. Cuando nazcan, en la fecha de pago de las nóminas (retenciones IRPF) o al finalizar el mes durante el cual fue declarado el concurso (cuota obrera TGSS), no serán créditos concursales sino créditos contra la masa (art. 84.2.5. ${ }^{\circ}$ ).

Conviene mencionar el art. 1090 del Código Civil, para recordar que el deber de retener a cuenta de los impuestos personales sobre la renta y de cotización a la Seguridad Social, causa de las obligaciones de pago a la Hacienda Pública y a la TGSS (prestación), nace de la Ley General Tributaria y de las Leyes de los Impuestos sobre la Renta de las Personas Físicas y de Sociedades, así como de la Ley General de la Seguridad Social (leyes especiales).

Se refieren a esta cuestión, relativa al derecho de crédito por retenciones del IRPF, las Sentencias pronunciadas por D. Javier Antón Guijarro, Magistrado-Juez de lo Mercantil n. ${ }^{\circ} 1$ de Oviedo, de fechas 31 de mayo de 2005 y 11 de mayo de 2006, en las que resuelve que únicamente las retenciones

\footnotetext{
${ }^{36}$ Gómez MARTín, F., «Periodificación salarial, tributaria y de cotizaciones sociales en el concurso de acreedores», Revista Técnica Tributaria, Asociación Española de Asesores Fiscales, Núm. 70, julio/septiembre 2005.
} 
practicadas con posterioridad a la fecha de declaración del concurso pueden ser tenidas como créditos contra la masa, en la medida en que traen causa en el ejercicio de la actividad empresarial del concursado desarrollado tras dicho momento y encuentran acomodo en el n. ${ }^{\circ} 5$ del Art. 84.2 LC, para lo cual la propia Ley atiende al momento de nacimiento del crédito no al de su exigibilidad, y así repara en que ambos momentos pueden aparecer disociados e incluso distantes en el tiempo en casos como el de las indemnizaciones por despido o extinción de los contratos de trabajo (n. ${ }^{\circ} 5$ Art. 84.2) o el de las obligaciones nacidas de la ley o de responsabilidad extracontractual del concursado (n. ${ }^{\circ} 10$ Art. 84. 2), a pesar de lo cual si su nacimiento fuera previo a la declaración del concurso serán en todo caso créditos concursales y no contra la masa.

\subsubsection{PERIODIFICACIÓN DEL IVA}

Si se acepta que la lista de acreedores debe referirse a la fecha del auto de declaración de concurso, puede darse el caso de la periodificación del IVA, en el supuesto temporal de que la fecha del auto de declaración de concurso sea distinta a la del final de un mes o trimestre, es decir, que proceda compensar los saldos figurados en las cuentas 472 «H, IVA soportado»y 477 «HP, IVA repercutido», del PGC, y que el exceso del IVA repercutido sobre el IVA soportado deducible sea abonado a la cuenta 4750 «P, acreedor por IVA», cuyo crédito será incluido en la lista de acreedores.

Con matices, es la autorizada opinión del Juzgado de lo Mercantil n. ${ }^{\circ} 1$ de Oviedo, en la Sentencia de fecha 26 de junio de 2005, al concluir que únicamente el crédito por IVA devengado con posterioridad a la fecha de declaración del concurso, con independencia del momento de su liquidación, puede disfrutar del reconocimiento de crédito contra la masa, y que no puede resultar relevante a esta finalidad el momento en que tenga lugar la liquidación del impuesto.

En parecidos términos resuelve el mismo Juzgado de lo Mercantil n. ${ }^{\circ} 1$ de Oviedo, en Sentencia de fecha 24 de junio de 2005, cuando considera que tales obligaciones tributarias por IVA únicamente pueden gozar del reconocimiento de créditos contra la masa si hubieran nacido en el espacio temporal que viene delimitado como dies a quo por el momento de declaración del concurso y como dies ad quem por aquél en que el juez acuerde el cese de la actividad profesional o empresarial, apruebe un convenio o, en otro caso, declare la conclusión del concurso, todo ello conforme se dispone en el art. 84-2-5. ${ }^{\circ}$ LC y que no puede, por lo tanto, desconocerse que la fecha de la declaración del concurso se erige por el legislador como el momento preciso y determinante para configurar los créditos que puedan nacer en lo sucesivo como créditos contra la masa.

El mismo Juzgado de lo Mercantil n..$^{\circ} 1$ de Oviedo, en la Sentencia de 11 de mayo de 2006, reitera el criterio expresado anteriormente. 


\subsubsection{FACTURAS RECTIFICATIVAS DEL IVA}

La Ley 62/2003, de 30 de diciembre, de medidas fiscales, administrativas y del orden social, en el art. 7, modifica la Ley 37/1992, de 28 de diciembre, del Impuesto sobre el Valor Añadido, e introduce la modificación del apartado tres del artículo 80 de la Ley 37/1992, de 28 de diciembre, del Impuesto sobre el Valor Añadido.

Dos aspectos se abordan en esta modificación, a saber: a) el sujeto pasivo podrá recuperar el IVA devengado cuando el destinatario de la operación sea declarado en concurso (insolvente), pero deberá hacerlo en el plazo de un mes a contar desde la última de las publicaciones acordadas en el auto de declaración de concurso; b) cuando se sobresea el proceso concursal [no expediente], el sujeto pasivo anteriormente mencionado deberá volver a repercutir el IVA recuperado. Son causas de conclusión (finalización y terminación) del concurso y archivo de las actuaciones [la nueva Ley no menciona sobreseimiento ${ }^{37}$ alguno, aunque puede considerarse sinónimo], las tasadas en el art. 176.

Conviene consultar el Real Decreto 87/2005, de 31 de enero, por el que se modifica el Reglamento del Impuesto sobre el Valor Añadido, aprobado por Real Decreto 1624/1992, de 29 de diciembre, el Reglamento de los Impuestos Especiales, aprobado por Real Decreto 1165/1995, de 7 de julio, y el Reglamento por el que se regulan las obligaciones de facturación, aprobado por Real Decreto 1496/2003, de 28 de noviembre, en particular, el artículo primero de modificación del citado Reglamento del Impuesto sobre el Valor Añadido, que modifica el artículo 24.

Conviene recordar que el sujeto pasivo podrá recuperar el IVA devengado cuando el destinatario de la operación sea declarado en concurso (insolvente), pero deberá hacerlo en el plazo de un mes a contar desde la última de las publicaciones acordadas en el auto de declaración de concurso.

En caso de que el destinatario de las operaciones tenga la condición de empresario o profesional, deberá comunicar a la Delegación o Administración de la Agencia Estatal de Administración Tributaria correspondiente a su domicilio fiscal la circunstancia de haber recibido las facturas rectificativas que le envíe el acreedor, y consignará el importe total de las cuotas rectificadas y, en su caso, el de las no deducibles, en el mismo plazo previsto para la presentación de la declaración-liquidación. Cuando el destinatario de las operaciones hubiese sido declarado en concurso y suspendido en sus facultades de administración, será la administración concursal la obligada a dicha comunicación. Además de la comunicación a que se refiere el párrafo anterior, en la declaración-liquidación correspondiente al período en que se hayan recibido las facturas rectificativas de las operaciones, el citado destinatario deberá hacer constar el importe de las cuotas rectificadas como mino-

${ }^{37}$ DRAE: Poner término al proceso judicial. 
ración de las cuotas deducidas. Dispone, con carácter general, que el destinatario de las operaciones presentará declaración-liquidación correspondiente al periodo en que se hayan recibido las facturas rectificativas y hará constar el importe de las cuotas rectificadas como minoración de las cuotas deducidas. Pero si el destinatario de las operaciones hubiese sido declarado en concurso, esta pretensión de que, por virtud de la «suma algebraica», se ingresen las cuotas rectificadas $\mathrm{u}$ opere la compensación, pugna con la esencia del Derecho concursal y puede violar uno de sus pilares básicos: la par conditio creditorum. Efectivamente, declarado el concurso, integran la masa pasiva todos los acreedores del deudor, ordinarios o no, cualquiera que sea su nacionalidad y domicilio, según dispone el art. 49 de la Ley concursal, y se observa en el art. 84.1, concordante con el anteriormente citado art. 49, que excluye de la masa pasiva, expresamente, los créditos contra la masa, es decir, entre otros, aquellos que la doctrina y la jurisprudencia viene denominando «deudas de la masa» y «créditos prededucibles». Pues bien, si se da el tratamiento reglamentario a las cuotas rectificadas, en sede concursal, se habrán convertido en créditos contra la masa. Parece más seguro, y respetuoso con el Derecho concursal, que el destinatario de la operación, declarado en concurso, cuando reciba las facturas rectificativas del sujeto pasivo, atribuya el crédito correspondiente a la Hacienda Pública, acreedor por IVA, en la masa pasiva, y se lo haga saber a la AEAT, por medio de la comunicación ordenada en este precepto, a la que acompañará la declaración-liquidación correspondiente, en la que dejará constancia del crédito nacido a favor de la Hacienda Pública, por subrogación, con cargo al sujeto pasivo acreedor.

La opinión expresada se observa en el Auto del Juzgado de 1. Instancia n. ${ }^{\circ} 9$ y Mercantil de Córdoba, de fecha 2 de junio de 2005: «Razonamientos Jurídicos. 6.- Tampoco cabe afirmar que como consecuencia de la emisión de las facturas rectificativas de IVA nazca o surja un crédito postconcursal (categoría, por cierto, inexistente en relación con la nueva legislación concursal, puesto que en el seno del procedimiento de concurso los créditos son o concursales o contra la masa, según establece el artículo 84 de la Ley Concursal), pues el crédito sigue siendo el mismo, si bien se modifica su titularidad, a través de una novación modificativa parcial en la persona del acreedor, en este caso la Agencia Tributaria».

No participa de esta interpretación Rodríguez ${ }^{38}$, quien presenta, entre otras, la siguiente conclusión: «6. El crédito que nace con motivo de la modificación de la base imponible del IVA surge con posterioridad a la declaración del concurso, en virtud de lo dispuesto en el artículo 80 apartado 3 y 114 apartado 2 número 2 in fine de la LIVA. De conformidad con el artículo 84

${ }^{38}$ RodRíGUEZ RodríGUEZ, Ángel, «La modificación de la base imponible del IVA ante la existencia de un proceso concursal», Contabilidad y Tributación. Comentarios y Casos Prácticos, núm. 278, mayo 2006, Centro de Estudios Financieros, pp. 83-98. 
apartado 2 número 10 de la LC dicho crédito tiene el carácter de crédito contra la masa y debe ser atendido a su vencimiento. El segundo de los preceptos antes mencionados obliga a que este crédito se incluya en la declaraciónliquidación a presentar en el período impositivo en que se ha recibido la factura rectificativa».

\subsubsection{CRÉDITOS SOMETIDOS A CONDICIÓN RESOLUTORIA O SUSPENSIVA}

El artículo 87 de la Ley concursal contempla determinados supuestos especiales de reconocimiento de créditos, particularmente aquellos sometidos a condición, resolutoria o suspensiva, los litigiosos y los afianzados.

Los créditos sometidos a condición suspensiva ${ }^{39}$ y los litigiosos ${ }^{40}$ serán reconocidos en el concurso como créditos contingentes sin cuantía propia y con la calificación que corresponda, admitiéndose a sus titulares como acreedores legitimados en el juicio, sin más limitaciones que la suspensión de los derechos de adhesión, de voto y de cobro. En todo caso, la confirmación del crédito contingente o su reconocimiento en sentencia firme o susceptible de ejecución provisional otorgará a su titular la totalidad de los derechos concursales que correspondan a su cuantía y calificación (art. 87.3).

Cuando el juez del concurso estimase probable la confirmación del crédito contingente, a petición de parte, podrá acordar las siguientes medidas cautelares: a) la constitución de provisiones con cargo a la masa, que no sé muy bien lo que quiere decir, aunque interpreto que la administración concursal deberá provisionar, o sea, anotar como contingencia, entre las obligaciones presuntas, el importe de dichas obligaciones sujetas a condición suspensiva; b) prestación de fianza; c) cualesquiera otras (art. 87.4). Las dotaciones de provisiones para estos riesgos, cuando el concursado fuese sujeto contable ${ }^{41}$, no ofrecerá dificultades a la administración concursal, para registrar u ordenar el correspondiente asiento contable. Sin embargo, cuando la situación patrimonial del deudor fuese deficitaria, dicha medida cautelar de constitución de provisiones contables no será efectiva, si por efectividad consideramos la retención o afectación de fondos propios a los derechos del titular del crédito contingente. Sobre la prestación de fianza, por parte del deudor, no parece que pueda ser personal ni de garantías personales de terceros,

${ }^{39}$ La condición es suspensiva cuando de su cumplimiento depende la existencia de la obligación. La obligación bajo condición suspensiva es la que puede existir o no existir, según que un acontecimiento futuro e incierto suceda o no suceda.

${ }^{40}$ STS (Sala de lo Civil) 28.02.1991. Fundamentos de Derecho. Sexto.

${ }^{41} \mathrm{El}$ concepto de sujeto contable se recupera de la doctrina en el Real Decreto 296/2004, de 20 de febrero, por el que se aprueba el régimen simplificado de la contabilidad, aunque ya se mencionó en la Disposición final Primera REAL DECRETO 1815/91, de 20 de diciembre, por el que se aprueban las Normas para la formulación de cuentas anuales consolidadas. 
así como tampoco cabe pensar en garantías reales constituidas sobre bienes de su masa activa a favor de acreedores contingentes, pues tales afianzamientos quebrantarían la pars conditio creditorum. Parece más seguro que la mención a las fianzas se refiere a las que puede exigir el Juez a terceros titulares de créditos sujetos a condición resolutoria, para tener derecho a figurar en lista de acreedores «con cuantía» y a su pleno ejercicio, como cualquier otro acreedor, con vistas al convenio, por ejemplo.

Sobre esta materia se pronuncia el Auto del Juzgado de lo Mercantil n. ${ }^{\circ} 4$ de Madrid, de fecha 3 de enero de 2005, y acuerda que como el acreedor dispone de una sentencia de condena dictada por el Juzgado de Primera Instancia confirmada en apelación, aunque no firme por mediar recurso de casación, contra la concursada, tras haber obtenido pronunciamiento favorable en las dos instancias, el juicio de probabilidad respecto al crédito de la acreedora debe resultar positivo, por lo que se cumple el requisito exigido por el n. ${ }^{\circ} 4 \mathrm{del}$ artículo 87 de la Ley Concursal para que resulte procedente la medida por ella instada; en este caso, la constitución de una provisión con cargo a la masa.

\subsection{Crédito bancario por efectos descontados}

Paradigma de créditos contingentes, con causa en condición suspensiva, son las «Deudas por efectos descontados», generalmente adeudadas a entidades de crédito, contrapartida contable de la rúbrica «Clientes efectos comerciales descontados». Se trata de una partida del pasivo exigible sujeto a condición suspensiva, aunque su inclusión en la lista de acreedores, por la administración concursal, dependerá del estudio particular del caso concreto, que obliga a incluir estos créditos sin cuantía, cuando los efectos no hayan vencido aún, o con el importe reclamado por la entidad de crédito, cuando justifique que han resultado impagados y los devuelva al cedentedescontante (concursado). Estos comentarios, pensando en la letra de cambio, pueden extenderse al pagaré y al cheque, consecuencia de su endoso.

Problemática similar a la expuesta, sobre la posición acreedora de las entidades de crédito, por descuento de efectos comerciales, se produce respecto de los acreedores a quienes se hubiese endosado efectos comerciales en cartera para pago de sus créditos pro solvendo. Su inclusión en la lista de acreedores «con cuantía» dependerá de que los endosatarios entreguen los títulos correspondientes a la administración concursal, bien por encontrarse los efectos endosados pendientes de vencimiento o por haber resultado impagados. En otro caso, es decir, si los conserva el acreedor, bien por su espera al vencimiento, que será lo normal, bien para el ejercicio de acciones contra el librado, la administración concursal incluirá el crédito «sin cuantía», por tratarse de créditos contingentes sujetos a condición suspensiva.

En la Primera Mesa Redonda del II Congreso de Derecho Mercantil, celebrado en Valencia, los días 1 y 2 de diciembre de 2005, sobre «Aspectos jurídicos de la formación de la lista de acreedores», se aborda esta cuestión: 
«¿Qué reconocimiento y calificación merece el crédito bancario por los efectos descontados que todavía estuviesen pendientes de vencimiento al tiempo de la declaración del concurso?... La clasificación concursal del crédito bancario por los efectos que todavía estuviesen pendientes de vencimiento debe reconducirse a la consideración de crédito contingente (arts. 87 n. ${ }^{\circ} 3$ y 5 de la Ley Concursal)... Procede, por lo tanto, distinguir entre efectos definitivamente impagados, que han de ser reconocidos como crédito concursal, y los pendientes de vencimiento, que se considerarán crédito contingente (arts. 87 n. ${ }^{\circ} 3$ y 5 de la Ley Concursal)».

\subsubsection{ClasifiCACIÓN DE CRÉDITOS}

Según la exposición de motivos:

«La regulación de esta materia de clasificación de los créditos constituye una de las innovaciones más importantes que introduce la ley, porque reduce drásticamente los privilegios y preferencias a efectos del concurso, sin perjuicio de que puedan subsistir en ejecuciones singulares, por virtud de las tercerías de mejor derecho. Se considera que el principio de igualdad de tratamiento de los acreedores ha de constituir la regla general del concurso, y que sus excepciones han de ser muy contadas y siempre justificadas...».

En el artículo 89 y en los inmediatos siguientes (90 a 93) de la Ley concursal, se comprueba la llamada poda de privilegios, en comparación con el Derecho concursal derogado, así como la nueva clasificación de créditos concursales: privilegio especial ex art. 90 (hipotecarios, prendarios, refaccionarios, leasing, etc.); privilegio general ex art. 91 (laborales e institucionales, etc.); ordinarios; y, subordinados ex art. 92 (morosos, participativos, intereses, sanciones, etc., y personas especialmente vinculadas con el deudor, según el art. 93).

\subsubsection{CLASIFICACIÓN DE CRÉDITOS AFIANZADOS}

Los créditos en los que el acreedor disfrute de fianza de tercero se reconocerán por su importe sin limitación alguna y sin perjuicio de la sustitución del titular del crédito en caso de pago por el fiador, como consecuencia natural de la facultad del acreedor afianzado a reclamar o no al fiador. En la calificación de estos créditos se optará, en todo caso, por la que resulte menos gravosa para el concurso entre las que correspondan al acreedor y al fiador, según dispone el art. 87.6. Se refiere a la clasificación que les corresponda ex arts. 89 a 92 y puede pretender que no mejore la calificación jurídica del crédito principal si disfrutase de mejor posición el fiador, es decir, cuando haya sido sustituido el titular del crédito, caso de pago por el fiador, se opta- 
rá, en la clasificación de estos créditos, por la que resulte menos gravosa para el concurso, entre las que corresponda al acreedor y al fiador ${ }^{42}$.

Merece lectura reposada la sentencia del Juzgado de lo Mercantil n. ${ }^{\circ} 1$ de Madrid, de fecha 5 de junio de 2005, que concluye que el sentido del artículo 87.6 inciso segundo LC es el de considerar postergados sólo aquellos créditos de los fiadores especialmente relacionados con el deudor, una vez que se hayan subrogado en la posición jurídica del acreedor principal, como consecuencia del pago.

La misma decisión adopta la Sentencia del Juzgado de lo Mercantil n. ${ }^{\circ}$ 1 de Oviedo, de fecha 8 de junio de 2005, y acuerda que la administración concursal deberá reconocer y calificar el derecho del acreedor principal conforme le corresponda, en aplicación de la clase de crédito de que se trate y del privilegio que legalmente pueda tener reconocido (arts. 89 a 92 LC), y únicamente en el caso de que el fiador lleve a cabo el pago al deudor concursado, y así lo comunique oportunamente a la administración concursa, será cuando entre en juego la aplicación del repetido inciso segundo del art. 87-6 LC, conclusión que por otra parte se ve reforzada si tenemos presente que la norma cuestionada se ubica sistemáticamente en sede de «Comunicación y reconocimiento de créditos» (Sección 2. ${ }^{a}$, Capítulo III, Título IV de la Ley) y no en sede de «Clasificación de los créditos» (Sección 3. ${ }^{a}$ ), como sería lógico en el caso de tratarse de una regla de subordinación legal.

De igual modo, la Sentencia del Juzgado de lo Mercantil n. ${ }^{\circ} 1$ de Sevilla, de fecha 14 de julio de 2005, que cita la anterior Sentencia de Oviedo, entre otras, considera que la tesis que ha dado en denominarse «literalista» descontextualiza el párrafo en que se prevé que «en la calificación de estos créditos se optará, en todo caso, por la que resulte menos gravosa para el concurso entre las que correspondan al acreedor y al fiador», y que el hecho de que el crédito goce de garantía personal no supone limitación alguna, ni cuantitativa ni cualitativa, a su reconocimiento, cuando el apartado 6 del art. 87 de la Ley concursal prevé expresamente la posibilidad de que el fiador, caso de pagar al acreedor, sustituya a éste en el concurso, y es en relación con esta previsión de subrogación que entra en juego el inciso objeto de la controversia. Efectivamente, si tal inciso no existiera, se daría la paradoja de que personas, concretamente las denominadas en el art. 92.5. ${ }^{\circ}$ de la Ley

\footnotetext{
${ }^{42}$ Sentencia del Juzgado de lo Mercantil n. ${ }^{\circ} 5$ de Madrid, de fecha 22.03.2005, y Acta de la reunión de Jueces de lo Mercantil de Madrid, de fecha 05.04.2005: «Que la interpretación más razonable del artículo 87.6 de la ley Concursal pasaría por entender que la calificación menos gravosa para el concurso entre las que corresponden al acreedor y al fiador sólo operaría en caso de que el fiador (que en ocasiones podría estar llamado a ser un subordinado) hubiese sustituido por el pago al acreedor, no siendo aplicable al crédito del acreedor cuando éste siga teniendo tal condición».
} 
concursal como «personas especialmente relacionadas con el deudor», definidas en el art. 93 de la Ley concursal, respecto de las que la Ley concursal ha previsto una «degradación» de su cualidad de acreedor, otorgando a los créditos de que son titulares la calificación de subordinados, eludirían estas consecuencias negativas mediante la subrogación en el lugar del acreedor al que han hecho pago del crédito en virtud de la fianza prestada, a la vista de la naturaleza de la institución de la subrogación (fundamentalmente, arts. 1212 y 1839 del Código Civil), conforme a la cual el fiador que paga y se subroga en el lugar del acreedor principal lo hace en la situación que éste tenía, es decir, con todos los derechos inherentes al crédito de este acreedor principal. Para evitar esta situación, el legislador introduce, a continuación de la previsión de subrogación del fiador solvens en el lugar del acreedor principal, el inciso en cuestión. Conforme a éste, estos créditos (los que ostentan los fiadores que se subroguen por pago al acreedor), en todo caso, serán calificados del modo menos gravoso para el concurso entre los que correspondan al acreedor y al fiador. Por ello, si el fiador es una persona especialmente relacionada con el concursado, el crédito que ostenta por subrogación será calificado como subordinado «en todo caso», es decir, ya fuera el crédito del acreedor principal un crédito ordinario, o fuera privilegiado Y también, por aplicación de la expresión «en todo caso», la calificación del crédito del fiador subrogado del modo menos gravoso para el concurso se producirá cuando se esté en la situación inversa, esto es, cuando fuera el crédito principal subordinado por ser el acreedor una persona especialmente relacionada con el concursado, y sin embargo carecer de tal cualidad el fiador.

Asimismo, la Sentencia del Juzgado Primera Instancia n. ${ }^{\circ} 9$ de Córdoba y de lo Mercantil de la Provincia, de fecha 28 de junio de 2005, interpreta que el artículo 87.6 sobre los créditos afianzados por personas especialmente relacionadas con el concursado no puede tener como consecuencia jurídica la aplicación a esos créditos de la calificación que correspondería al crédito de reembolso de esas personas, mientras no se haya producido el pago del garante y, con él, la sustitución en la titularidad del crédito, pues no puede sancionarse al acreedor afianzado hasta el extremo, dados los gravosos efectos que la subordinación produce, de anular el valor de este crédito en el concurso, y acuerda que la administración concursal ha de reconocer el crédito del acreedor con fianza de tercero, antes de que éste haya pagado, por su importe y sin limitación alguna, y clasificarlo dentro de la clase que le corresponda conforme a los artículos 89 y siguientes de la Ley concursal, sin que la que pudiera corresponder, en su caso, al crédito del fiador influya ni condicione en forma alguna aquella calificación, puesto que la norma contenida en el último inciso del apartado 6 del artículo 87 sólo es de aplicación en el supuesto de que el fiador se haya subrogado por pago en el crédito afianzado y el acreedor o el fiador sean personas especialmente relacionadas con el deudor. 
En la Primera Mesa Redonda ${ }^{43}$ del II Congreso de Derecho Mercantil, celebrado en Valencia, los días 1 y 2 de diciembre de 2005, sobre «Aspectos jurídicos de la formación de la lista de acreedores», se aborda esta cuestión: «Los acreedores titulares de un crédito afianzado por un tercero especialmente relacionado con el deudor ¿deben ver calificado su crédito privilegiado como subordinado? Se reconoce que, hasta el momento, las resoluciones judiciales dictadas sobre el alcance del artículo 87.6. ${ }^{\circ} \mathrm{LC}$, y se decantan por la llamada interpretación correctora versus literalista.

En la misma dirección el dictamen de Olivencia, de fecha 23 de marzo de 2005, que presenta las siguientes conclusiones:

«Primera.- En caso de concurso del deudor, la administración concursal ha de reconocer el crédito del acreedor con fianza de tercero, antes de que éste haya pagado, por su importe y sin limitación alguna, y clasificarlo dentro de la clase que le corresponda, conforme a los arts. 89 y siguientes de la Sección 3A del Capítulo III del Título IV LC, sin que la que pudiera corresponder, en su caso, al crédito del fiador influya ni condicione en forma alguna aquella calificación. Segunda.- La norma contenida en el último inciso del apartado 6 del artículo 87 sólo es de aplicación en el supuesto de que el fiador se haya subrogado por pago en el crédito afianzado y el acreedor o el fiador sean personas especialmente relacionadas con el deudor. Tercera.- En el supuesto contemplado en la conclusión anterior, el crédito concursal será clasificado de subordinado, con pérdida de las garantías de cualquier clase constituidas a su favor. Cuarta.- El caso de la fianza real y de subrogación por pago del garante no entra en el supuesto de hecho del art. 87.6, ni le es, por tanto, aplicable la consecuencia prevista en su último inciso, porque se trata de una norma excepcional y no procede su aplicación analógica ni su interpretación extensiva».

Sin embargo, me parece más segura la interpretación del maestro Rojo ${ }^{44}$, que presenta la siguiente conclusión: «La norma legal analizada es una norma dura y asimétrica; pero responde a unos postulados de política Legislativa -es decir, que tiene un "espíritu" y una "finalidad"- que son coherentes con la "funcionalidad" del sistema concursal instaurado por la Ley 22/2003, de 9 de julio. No es posible negar que se trata de una norma discutible en el plano de las opciones de política legislativa. Pero no se trata de una norma que no sea clara, aunque las consecuencias de la aplicación de la misma no satisfagan a determinadas "categorías" de acreedores o a determinados estu-

${ }^{43}$ Relator: Antoni Frigola, Magistrado, Juzgado de lo Mercantil n. ${ }^{\circ} 1$ de Madrid. Intervinientes: Enrique García García, Magistrado, Juzgado de lo Mercantil n. ${ }^{\circ} 4$ de Madrid y Rafael Fuentes Devesa, Magistrado, Juzgado de lo Mercantil de Alicante.

${ }^{44}$ ROJO FERNÁNDEZ DEL Río, Á., «La calificación de los créditos concúrsales con garantía personal», Boletín del Colegio de Abogados de Madrid, n. ${ }^{\circ} 32,3^{\text {a }}$ época, enero 2006, pp. 13-39. 
diosos. Esa "insatisfacción", sin embargo, no legitima para forzar los textos legales a fin de que digan aquello que no dicen, por muy autorizadas que sean las opiniones en las que se pretenda fundamentar esa "tergiversación" del dato normativo. Si la norma se considera desacertada y peligrosa, debe impetrarse del legislador la modificación o la derogación de la misma. Ése -y sólo ése- es el camino. En tanto no tenga lugar esa modificación o esa derogación, hay que aplicarla en los términos en que ha sido concebida y aprobada».

\subsubsection{CLASIFICACIÓN DE LOS SALARIOS DE TRAMITACIÓN, POSTERIORES A LA DECLARACIÓN DE CONCURSO, DE LAS PAGAS EXTRAORDINARIAS}

En la Primera Mesa Redonda del II Congreso de Derecho Mercantil, celebrado en Valencia los días 1 y 2 de diciembre de 2005, sobre «Aspectos jurídicos de la formación de la lista de acreedores», se aborda esta cuestión:

«Los créditos por salarios de tramitación fijados por resolución judicial dictada con posterioridad a la declaración de concurso, ¿cómo se clasifican?». Ante las dos opciones planteadas: a) si se equiparan a salarios o b) si se equiparan a indemnizaciones, se inclinan a favor de la interpretación estricta:

I) el art. 84.2.1 se refiere a salarios en tanto que los arts. 84.2.5 y 91.1 contemplan expresamente salario e indemnizaciones, por lo que parece que discrimina al no equipararlo.

II) el art. 84.2.1 habla de salario por los últimos treinta días de trabajo, por lo que parece referirse a salarios en sentido estricto, por el trabajo efectivo (art. 26.1 ET) y no indemnizaciones que no es salario (art. 26.2 ET).

III) el art. 32.1 ET, que es el equivalente extraconcursal al art. 84.2.1, habla de salario en tanto que la equiparación a efectos de preferencia la establece el art. 32.3 ET, según redacción dada por la LC (Disposición final decimocuarta).

IV) la doctrina jurisprudencial social otorga naturaleza indemnizatoria a los salarios de tramitación.

Sobre la clasificación de las pagas extraordinarias, resuelve la Sentencia del Juzgado de lo Mercantil n. ${ }^{\circ} 5$ de Madrid, de fecha 21 de marzo de 2005: a) rechaza la pretensión de que para determinar el salario mínimo interprofesional, que sirve de base para el cálculo del límite del privilegio, deba incluirse la parte proporcional de las dos pagas extraordinarias; $b$ ) en cuanto a la forma de determinación del número de días de salario pendientes de pago, la forma adecuada de calcularla es dividiendo el total de deuda pendiente de pago por el salario diario del trabajador, incluido el prorrateo de pagas extraordinarias; c) el crédito del impugnante, en concepto de pagas extraordinarias, debe clasificarse como crédito con privilegio general del $n .^{\circ}$ 
1 del artículo 91 de la LC, y en lo que exceda el total de los créditos por salarios adeudados, del triple del salario mínimo interprofesional, sin incluir el prorrateo de pagas extraordinarias, multiplicado por el número de días de salario pendientes de pago, se calificará como crédito ordinario.

\subsubsection{CLASIFICACIÓN DEL CRÉDITO TRIBUTARIO Y DE LA TESORERÍA GENERAL DE LA SEGURIDAD SOCIAL}

Los créditos públicos pueden clasificarse en cualquiera de las categorías establecidas en el art. 89.

\subsection{Privilegio general ex art. 91.4}

Se ha suscitado abundante litigiosidad sobre la clasificación de los créditos tributarios y de la Tesorería General de la Seguridad Social, que ha sido objeto de numerosas Resoluciones por los Juzgados de lo Mercantil, no siempre pacíficas, en particular, respecto del privilegio general del art. $91.4^{45}$, a cuyo $50 \%$, calculado sobre la suma de créditos que no gozan de privilegio especial, ni traen causa en retenciones de los impuestos personales sobre la renta o de cotizaciones sociales de los trabajadores, ni han sido postergados como subordinados (intereses y sanciones), se atribuye mayoritariamente privilegio general, y al restante $50 \%$ la calificación jurídica de crédito ordinario. Sobre el método para el cálculo del privilegio general del art. 91.4. ${ }^{\circ}$, además de las resoluciones mencionadas, se pronuncia la Sentencia del Juzgado de lo Mercantil n. ${ }^{\circ} 1$ de Oviedo, de fecha 31 de mayo de 2005, y considera que la expresión discutida y poco afortunada del «conjunto de los créditos», empleada por el inciso segundo del apartado $4 .^{\circ}$ del art. $91 \mathrm{LC}$, deberá ser interpretada en una hermenéutica razonable de la norma, trascendiendo su mera literalidad (art. 3-1 C. Civil), teniendo presente su ubicación sistemática dentro del propio art. 91 como un cómputo selectivo comprensivo únicamente del conjunto de las cantidades restantes y que no gocen de ningún otro privilegio, pues una interpretación distinta conduciría, además, al tratamiento injustificado de dotar de un doble privilegio a las sumas por

${ }^{45}$ Sentencia del Juzgado de lo Mercantil n. ${ }^{\circ} 3$ de Madrid, de 04.03.2005; SJM de Navarra, de 23.03.2005; SJM n. ${ }^{\circ} 2$ de Barcelona, de 29.03.2005; SJM n. ${ }^{\circ} 5$ de Madrid, de 29.03.2005; SJM n. ${ }^{\circ} 4$ de Barcelona, de 04.04.2005; SJM de Navarra, de 02.05.2005; SJM de Alicante, de 05.05.2005; SJM n. ${ }^{\circ} 4$ de Madrid, de 17.06.2005; SJM de Santander, de 10.06.2005; SJM de Vitoria, de 23.09.2005; SJM de Santander, de 29.09.2005; SJM n. ${ }^{\circ} 5$ de Madrid, de 29.03.2005; SJM de Santander, de 30.09.2005.

«Nuevo Derecho Concursal», Abogado, con la colaboración de Fernando Gómez Martín, Auditor de cuentas, Profesores de Derecho concursal en la Universidad de Deusto, Bilbao, 2005. 
retenciones, una primera ex apartado $2 .^{\circ}$ del art. 91 y una segunda al utilizarlas además para el cómputo del privilegio del apartado $4 .^{\circ}$.

De igual manera, interesa destacar la sentencia del Juzgado de lo Mercantil n. ${ }^{\circ} 2$ de Madrid, de fecha 23 de junio de 2005, la cual interpreta que la base a la que debería aplicarse el porcentaje del $50 \%$ estaría constituida por el importe del privilegio definido en la primera parte de la norma (art. 91.4. ${ }^{\circ}$ ), es decir, el que resulta de deducir, de los créditos que menciona, el importe de otros privilegios (los contemplados en los arts. 90.1.1. ${ }^{\circ}$ y 91.2 de la Ley concursal), y que si el art. 91.4. ${ }^{\circ}$ no hace referencia a la necesidad de deducir -además de los otros privilegios-el importe de los créditos subordinados para hallar la base a la que aplicar el 50\%, ello se debe, bien a un olvido involuntario, o bien -acaso con mayor probabilidad de acierto- a consideraciones de carácter sistemático derivadas de que, no estando destinado el precepto a disciplinar el tratamiento de los créditos subordinados, no se consideró necesaria esa específica matización, tal vez por reputarse sobrentendida en la propia naturaleza y finalidad de la subordinación crediticia.

Interpretación diferente se deduce de la Sentencia del Juzgado de lo Mercantil de Vitoria, de fecha 23 de septiembre de 2005, la cual reputa inteligencia correcta la que desemboca en el cálculo de la lista de acreedores, de excluir de la base de cálculo los créditos subordinados, extraer el cincuenta por ciento del resto de créditos públicos, y de éste descontar lo ya privilegiado conforme arts. 90 y 91.2. ${ }^{\circ}$ LC.

Idéntica fórmula de cálculo, para la clasificación del art. 91.4. ${ }^{\circ}$, referido al crédito de la TGSS, se observa en la Sentencia del Juzgado de lo Mercantil n. ${ }^{\circ} 1$ de Bilbao, de fecha 15 de febrero de 2006, que cita la anterior de Vitoria, así como la doctrina del Profesor González Bilbao, es decir, considera el conjunto de los créditos de la administración pública, como minuendo, de los que detrae los subordinados (intereses, sanciones y recargos), como sustraendo, para calcular el 50\% del resto, que será el límite de los tres privilegios que establecen los arts. 90.1, 91.2. ${ }^{\circ}$ y 91.4. ${ }^{\circ}$.

La Sentencia del Juzgado de lo Mercantil número 1 de Málaga, de fecha 29 de marzo de 2006, mantiene el criterio mayoritario, aunque se hace eco de las interpretaciones de otros Juzgados de lo Mercantil, para concluir que la fijación de la base para el cálculo ha de hacerse recogiendo los créditos de la Seguridad Social o de la Hacienda Pública, partiendo de los créditos existentes y que no gocen de privilegio especial conforme al apartado 1 del artículo 90, ni del privilegio general del número $2 .^{\circ}$ de este artículo, es decir, es el conjunto de los créditos referidos (excluidos los señalados) los que el legislador ha querido que formen parte de la base para el cálculo que posteriormente se fija, y plantea si para el cálculo de dicho porcentaje se ha de recoger en la base la cuantía de los créditos subordinados, considerando que procede excluir de dicha base su cuantía por la propia naturaleza de los créditos subordinados. 
El mismo criterio parece desprenderse de la Sentencia del Juzgado de lo Mercantil n..$^{\circ} 1$ de Oviedo, de fecha 10 de mayo de 2006, que reitera la interpretación citada en su Sentencia de fecha 31.05.2005.

En la Primera Mesa Redonda ${ }^{46}$ del II Congreso de Derecho Mercantil, celebrado en Valencia los días 1 y 2 de diciembre de 2005, sobre «Aspectos jurídicos de la formación de la lista de acreedores», se aborda esta cuestión:

«Los métodos de cálculo del privilegio regulado en el artículo 91.4. ${ }^{\circ}$ LC. Sin embargo, no es una dificultad insalvable, si entendemos que con la expresión "conjunto de todos sus créditos" el legislador no se está refiriendo a los créditos que hayan sido calificados con privilegio especial, general del artículo $91.2 .^{\circ} \mathrm{LC}$ y subordinados, sino para referirse al resto, que también configuran un conjunto de créditos de Hacienda Pública o de la Tesorería General de la Seguridad Social. De este modo la expresión "conjunto de todos sus créditos" se quiere referir globalmente y sin exclusiones a la multiplicidad de tributos existentes en nuestro ordenamiento, según lo previsto en el artículo 2 LGT...».

El magistrado Rodríguez Achúteguii ${ }^{47}$, además de estudiar la calificación del recargo como subordinado, repasa las tesis de las administraciones públicas y la opuesta, defendida por el profesor González Bilbao ${ }^{48}$, así como una tesis intermedia que están manteniendo los Juzgados Mercantiles, mayoritariamente, y destaca que esta última disminuye el importe del crédito público con privilegio general, pero no lo excluye totalmente.

El Anteproyecto de Ley sobre concurrencia y prelación de créditos en caso de ejecuciones singulares, del Ministerio de Justicia, fechado en febrero de 2006, en su afán de blindar el cálculo del privilegio especial ex art. 91.4. ${ }^{\circ}$, incluye la siguiente Disposición final séptima:

«Modificación de la Ley 22/2003 de 9 de julio, Concursal. El número 4 del artículo 91 de la Ley 22/2003 de 9 de julio, Concursal, queda redactado como sigue: 4 . Los créditos tributarios y demás de derecho público así como los créditos de la Seguridad Social, incluidos los recargos, que no gocen de privilegio especial conforme al apartado 1 del artículo 90, ni del privilegio general del número $2 .^{\circ}$ de este artículo. En caso de convenio concursal, el privilegio general previsto en este apartado que-

\footnotetext{
${ }^{46}$ Relator: Antoni Frigola, Magistrado, Juzgado de lo Mercantil n. ${ }^{\circ} 1$ de Madrid. Intervinientes: Enrique García García, Magistrado, Juzgado de lo Mercantil n. ${ }^{\circ} 4$ de Madrid y Rafael Fuentes Devesa, Magistrado, Juzgado de lo Mercantil de Alicante.

${ }^{47}$ RodríGUEZ ACHÚteGUI, E., «El privilegio general del art. 91.4 de la Ley concursal», Repertorio de Jurisprudencia Aranzadi, n. ${ }^{\circ}$ 3, abril 2006, pp. 11-18.

${ }^{48}$ GonzÁlez BilbaO, E., «El ejercicio del privilegio general de los créditos públicos en el concurso. Un caso práctico», (BIB 2005, 1421), Actualidad Jurídica Aranzadi, núm. 680, 8 de septiembre de 2005, pp. 10-12.
} 
daría limitado hasta una cantidad máxima equivalente al cincuenta por ciento del conjunto de los créditos de la Hacienda Pública y para el conjunto de los créditos de la Seguridad Social, respectivamente. A los solos efectos del cálculo de dicho porcentaje, se incluirán los créditos que tengan la calificación de privilegiados especiales, con privilegio general del número $2 .^{\circ} \mathrm{y}$ subordinados».

\subsection{Recargos}

Respecto de la clasificación de los recargos tributarios como créditos subordinados, entre otras ${ }^{49}$, se pronuncia la Sentencia del Juzgado de lo Mercantil n. ${ }^{\circ} 1$ de Madrid, de fecha 5 de julio de 2005, y considera que el recargo es una pena -en el sentido de «castigo impuesto por autoridad legítima» (DRAE)- al que infringe la ley, y estaríamos ante un supuesto de hecho consistente en la infracción del imperativo de presentar la declaración y consiguiente ingreso tributario dentro de plazo, que conllevaría el «castigo» de abonarlo, y tal castigo cumple fielmente con el propósito de la sanción, esto es, estimular el pago dentro del periodo previsto. Función que es la que imprime el carácter sancionador al recargo, según se expresa en la STC 164/1995, de 13 de noviembre.

De igual modo, entre las resoluciones mencionadas, sobre clasificación del recargo de apremio como subordinado, se destaca la sentencia del Juzgado de lo Mercantil n. ${ }^{\circ} 1$ de Oviedo, de fecha 27 de de mayo de 2005, la cual interpreta que el carácter de orden público, en lo que al establecimiento de los privilegios y su clasificación se refiere, queda expresamente reflejada en el apartado 3 del art. 100 LC, al proscribir el legislador «la alteración de la clasificación de créditos establecida por la Ley», todo lo cual conduce a apreciar de oficio la clasificación como crédito subordinado respecto de los recargos tributarios.

Asimismo, la sentencia del Juzgado de lo Mercantil n. ${ }^{\circ} 5$ de Madrid, de fecha 29 de marzo de 2005, considera que el recargo de apremio ordinario no sólo es compatible con los intereses de demora sino que, además, lo es con los recargos por declaración extemporánea (artículo 27.4) y con las propias sanciones tributarias (artículo 180.4), por lo que si no tiene finalidad resarcitoria y su finalidad disuasoria queda francamente disminuida, dicha figura tiene unos contornos aún más próximos a las sanciones en sentido propio, que los recargos por declaración extemporánea, tengan o no una finalidad represiva, que es lo que el Tribunal Constitucional exige para la aplica-

${ }^{49}$ Sentencia J. M. n. ${ }^{\circ} 2$ Barcelona, de 29.03.2005; Sentencia J. M. n. ${ }^{\circ} 4$ Barcelona, de 04.04.2005; SJM n. ${ }^{\circ} 2$ Barcelona, de 11.04.2005; Sentencia, de 21.04.2005, JM n. ${ }^{\circ} 4$ Madrid; SJM Oviedo S. 27.05.2005; SJM n. ${ }^{\circ} 1$ Madrid, de 05.06.2005; JM n. ${ }^{\circ} 2$ Madrid, S. de 23.06.2005; SJM n. ${ }^{\circ} 1$ Madrid, de 5.07.2005. 
ción de las garantías del procedimiento sancionador, lo que permite someter a los recargos al régimen de subordinación de la Ley Concursal.

También la citada Sentencia del Juzgado de lo Mercantil n. ${ }^{\circ} 1$ de Bilbao, de fecha 15 de febrero de 2006, considera que es aplicable a la naturaleza del recargo de la TGSS el art. 92.4. ${ }^{\circ}$, la STC 276/2000, la cual llega a la conclusión de que «En definitiva, el recargo del 50 por 100 de la deuda tributaria establecido en el art. 61.2 LGT, en su redacción dada por la Ley 18/1991, en tanto que -supone una medida restrictiva de derechos que se aplica en supuestos en los que ha existido una infracción de la Ley y desempeña una función de castigo, no puede justificarse constitucionalmente más que como sanción» (FJ 6. ${ }^{\circ}$ ), y la misma línea interpretativa siguen las STC 201/1996, de 29 de enero de 2001 (RTC 2001\26), 93/2001, de 2 de abril (RTC 2001\93) y 127/2002, de 23 de mayo (RTC 2002\127), de todo ello se deduce que es aplicable a la naturaleza del recargo de la TGSS el art. 92.4 LC y la calificación como subordinado».

En la Primera Mesa Redonda del II Congreso de Derecho Mercantil, celebrado en Valencia los días 1 y 2 de diciembre de 2005, sobre «Aspectos jurídicos de la formación de la lista de acreedores», se aborda la clasificación de los recargos tributarios y se considera que al calificarse por el artículo 25.1 LGT los recargos de apremio como prestaciones accesorias, existe soporte suficiente como para mantener la clasificación de éstos como créditos subordinados sobre la base de la Ley concursal, puesto que ésta se apoya en el carácter accesorio de los créditos para atribuirles la calificación de subordinados.

Sin embargo, el Anteproyecto de Ley sobre concurrencia y prelación de créditos en caso de ejecuciones singulares, del Ministerio de Justicia, fechado en febrero de 2006, propone zanjar la polémica expuesta e incluye la siguiente Disposición final séptima: «Modificación de la Ley 22/2003 de 9 de julio, Concursal. El número 4 del artículo 91 de la Ley 22/2003 de 9 de julio, Concursal, queda redactado como sigue: 4. Los créditos tributarios y demás de derecho público así como los créditos de la Seguridad Social, incluidos los recargos, que no gocen de privilegio especial conforme al apartado 1 del artículo 90, ni del privilegio general del número $2 .^{\circ}$ de este artículo...».

\subsection{Clasificación del crédito tributario, caso de convenio concursal}

La nueva Ley 58/2003, de 17 de diciembre, General Tributaria, dispone: «Artículo 77. Derecho de prelación... 2. En caso de convenio concursal, los créditos tributarios a los que afecte el convenio, incluidos los derivados de la obligación de realizar pagos a cuenta, quedarán sometidos a lo establecido en la Ley 22/2003, de 9 de julio, Concursal [arts. 55, 84.2.5., 85, 90.1.1. ${ }^{\circ}, 91.2^{\circ}{ }^{\circ}$ y 4. $\left.{ }^{\circ}, 92\right] »$. Se modifica, por tanto, el artículo 71 de la anterior LGT de 1963, objeto de nueva redacción por la disposición final undécima de la Ley concursal, con el siguiente texto: «2. En caso de concurso, 
los créditos tributarios quedarán sometidos a lo establecido en la Ley Concursal». El citado art. 77 pretende sustraer de los efectos del concurso a los créditos tributarios, cuando finalice por liquidación.

El convenio concursal afectará siempre a los créditos tributarios con privilegio general no ejercible (art. 91.4 ${ }^{\circ}$ ), que la doctrina de los Juzgados de lo Mercantil clasifica como créditos ordinarios, es decir, al cincuenta por ciento del conjunto de los créditos de la Hacienda Pública, una vez deducidos los créditos que no gozan de privilegio especial, ni traen causa en retenciones de los impuestos personales sobre la renta o de cotizaciones sociales de los trabajadores, ni han sido postergados como subordinados (intereses, sanciones y recargos); pero puede afectar, también, al crédito tributario con privilegio especial y al general ejercitable, cuando la Hacienda Pública haya suscrito o se haya adherido al convenio de masa. Sin embargo, el cambio introducido no debe permitir que se pierda la perspectiva concursal sobre composición de la masa pasiva ex art. 84, es decir, no debe olvidarse que constituyen la masa pasiva todos los créditos contra el deudor común, según el art. 49, también los créditos tributarios, cualquiera que fuese su calificación jurídica (clasificación de créditos ex art. 89), que quedan sometidos a lo establecido en la Ley concursal ${ }^{50}$.

Así se interpreta en la Sentencia del Juzgado de lo Mercantil n. ${ }^{\circ} 1$ de Madrid, de fecha 5 de julio de 2005, cuando señala que la Disposición Adicional Octava de la LGT establece «lo dispuesto en esta Ley se aplicará de acuerdo con lo establecido en la legislación concursal vigente en cada momento», y denota la voluntad del legislador de que la Ley General Tributaria sea interpretada de manera que se ajuste en cada momento a la «legislación concursal vigente», lo cual revela de manera terminante la voluntad del legislador de no dotar al artículo 77 LGT de la eficacia parcialmente derogatoria de la Ley Concursal -para los créditos tributarios en casos de liquidación del patrimonio del concursado- que pretende la Agencia Tributaria.

En la Primera Mesa Redonda del II Congreso de Derecho Mercantil, celebrado en Valencia los días 1 y 2 de diciembre de 2005, sobre «Aspectos jurídicos de la formación de la lista de acreedores», se aborda el artículo 77 LGT y se alcanza la misma conclusión expuesta en la Sentencia anterior.

El mencionado anteproyecto de Ley sobre concurrencia y prelación de créditos en caso de ejecuciones singulares, del Ministerio de Justicia, fechado en febrero de 2006, incluye la siguiente Disposición final séptima, que inclina la balanza a favor de los créditos públicos, en caso de liquidación: «Modificación de la Ley 22/2003 de 9 de julio, Concursal. El número 4 del artículo 91 de la Ley 22/2003 de 9 de julio, Concursal, queda redactado como sigue: 4. Los créditos tributarios y demás de derecho público, así como

${ }^{50}$ Acta de la Junta de Jueces de lo Mercantil, celebrada el día 5 de abril de 2005, y Sentencia de la Magistrada del Juzgado de Primera Instancia n. ${ }^{\circ} 10$ y de lo Mercantil de Santander, de junio de 2005. 
los créditos de la Seguridad Social, incluidos los recargos, que no gocen de privilegio especial conforme al apartado 1 del artículo 90, ni del privilegio general del número $2 .^{\circ}$ de este artículo. En caso de convenio concursal, el privilegio general previsto en este apartado quedaría limitado hasta una cantidad máxima equivalente al cincuenta por ciento del conjunto de los créditos de la Hacienda Pública y para el conjunto de los créditos de la Seguridad Social, respectivamente. A los solos efectos del cálculo de dicho porcentaje, se incluirán los créditos que tengan la calificación de privilegiados especiales, con privilegio general del número $2 .^{\circ} \mathrm{y}$ subordinados».

\subsubsection{CLASIFICACIÓN DE LOS CRÉDITOS POR TRABAJO PERSONAL NO DEPENDIENTE}

Dispone el art. 91: «Son créditos con privilegio general. 3. ${ }^{\circ}$ Los créditos por trabajo personal no dependiente y los que correspondan al propio autor por la cesión de los derechos de la explotación de la obra de propiedad intelectual, devengados durante los seis meses anteriores a la declaración del concurso».

A estos créditos se refiere la Sentencia del Juzgado de lo Mercantil n. ${ }^{\circ} 1$ de Málaga, de fecha 29 de marzo de 2006, aunque limita este privilegio general cuando sus titulares son profesionales personas físicas.

\subsubsection{PRIVILEGIO ESPECIAL DEL INSTANTE DEL CONCURSO NECESARIO}

Dispone el art. 91: «Son créditos con privilegio general. 6. Los créditos de que fuera titular el acreedor que hubiere solicitado la declaración de concurso y que no tuvieren el carácter de subordinados, hasta la cuarta parte de su importe».

A estos créditos se refiere la Sentencia del Juzgado de lo Mercantil n. ${ }^{\circ} 1$ de Málaga, de fecha 29 de marzo de 2006, cuando son varios los instantes de la declaración de concurso necesario, y considera que la interpretación del precepto debe realizarse prorrateando la cuarta parte, en función del número de solicitantes, sin que este privilegio general afecte al $25 \%$ de cada uno de los créditos, sino que afectará exclusivamente a la parte prorrateada correspondiente de su crédito en función de ese $25 \%$.

\subsubsection{LEASING Y RENTING}

La finalidad del siguiente resumen es concretar el tratamiento de los créditos por cesión de bienes en arrendamiento financiero ${ }^{51}$, cuando el arrenda-

${ }^{51}$ La Ley 28/1998, de 13 de julio, de Venta a Plazos de Bienes Muebles (BOE 14.07.1998), con vigencia a partir del 23 de septiembre de 1998, dedica la Disposición Adicional Primera a los contratos de arrendamiento financiero, a su vez modificada por la Disposición Final Séptima de la nueva LEC. 
tario es declarado en concurso de acreedores, aunque he incluido algunas referencias a los créditos concursales con garantías reales:

Primero. La disposición del art. 49 implica que todos los acreedores (ordinarios o no, es decir, también los privilegiados), declarado el concurso, integran la masa pasiva, es decir, no pueden hacer efectivos sus créditos, lo cual significa que el concursado no les puede pagar, con algunas excepciones (art. 55, entre otros).

Segundo. Los acreedores con garantía real, sobre bienes afectos al proceso productivo, profesional o empresarial, no pueden ser pagados durante la tramitación del concurso, hasta que se apruebe un convenio o transcurra un año desde la declaración de concurso, sin que se hubiese aperturado la liquidación (art. 56.1).

Tercero. Los créditos por cesión de bienes en arrendamiento financiero de bienes afectos al proceso productivo, profesional o empresarial, no pueden ser pagados durante la tramitación del concurso, en las mismas condiciones temporales que los anteriores créditos con garantía real.

Cuarto. Unos y otros (créditos con garantía real o por cesión de bienes en arrendamiento financiero) son clasificados con privilegio especial y gozan de derecho de abstención, pero carecen del derecho de ejecución separada que disfrutaban con la legislación concursal derogada.

Quinto. El contrato de arrendamiento financiero, formalizado antes de la declaración de concurso, no es un contrato con prestaciones recíprocas pendiente de cumplimiento por ambas partes, sino un contrato atípico, según la mejor doctrina ${ }^{52}$, en el que una de las partes (el arrendador financiero) ha cumplido íntegramente sus obligaciones, y la otra (el arrendatario) tiene pendiente el cumplimiento total o parcial de las recíprocas a su cargo, es decir, el pago de cuotas e intereses, cuya deuda se incluirá en la masa pasiva del deudor (el concursado), según el art. 61.1.

Sexto. El apartado 2 del art. 61 dispone la vigencia de los contratos con obligaciones recíprocas pendientes de cumplimiento por ambas partes, que nada tiene que ver con el supuesto anterior, v. g. compraventa pendiente de perfeccionarse; tracto sucesivo; etc.

Séptimo. El acreedor con garantía real no puede iniciar la ejecución una vez declarado el concurso del deudor, con los límites temporales indicados (art. 56.1), y las iniciadas antes de la declaración del concurso son objeto de paralización de acciones o suspensión de actuaciones, durante un año desde la declaración de concurso, salvo que estuviese anunciada la subasta con

52 «... ya se entienda que el leasing constituye un negocio mixto, en el que se funden la cesión del uso y la opción de compra con causa única, ora que se trate de supuestos de conexión de contratos que debe ser reconducido a unidad esencial, el parecer más autorizado, y desde luego mayoritario, lo conceptúa de contrato complejo y atípico, gobernado por sus específicas estipulaciones y de contenido no uniforme» (Sentencias de 10 de abril de 1981, 18 de noviembre de 1983, 28 de mayo de 1990). 
anterioridad y la ejecución no recaiga sobre bienes o derechos necesarios para la continuidad de las actividades del deudor (art. 56.2).

Octavo. Igual tratamiento para la recuperación de los bienes muebles vendidos a plazo y de los cedidos en arrendamiento financiero, formalizados en documento público o debidamente inscritos en el Registro Mercantil, es decir, limitaciones al derecho de separación (art. 56.1).

Noveno. En el caso de transformación del crédito de leasing, como consecuencia del ejercicio de la opción de pago por la administración concursal, aunque se modifique la condición del crédito, se mantienen los derechos del privilegio especial sobre el bien afecto. Esta opción pasa por atender el pago de los créditos con privilegio especial con cargo a la masa, conforme a lo dispuesto en el artículo 155.2 de la Ley concursal. La administración concursal habrá de satisfacer de inmediato la totalidad de los plazos y la amortización de intereses vencidos. Se exige, pues, el pago de las cuotas e intereses vencidos. Pero respecto de los sucesivos pagos, la administración concursal asumirá la obligación de atenderlos como créditos contra la masa. Esta medida implica que el crédito con privilegio especial pase a ser considerado crédito contra la masa y debe ordenarse dentro del grupo de los acreedores contra la masa, conforme a las fechas de sus respectivos vencimientos, lo que ocurrirá con el vencimiento de cada una de las cuotas futuras y sus intereses. Sin embargo, esa decisión que supone la suspensión de los derechos anudados a los créditos con privilegio especial, al considerarse crédito contra la masa, se corrige en el mencionado artículo 155.2 in fine, pues en el caso de incumplimiento de los pagos sucesivos, se realizarán los bienes y derechos afectos para satisfacer los créditos con privilegio especial. Es decir, que ya no cabrán más opciones y que se mantiene ese derecho de ejecución individual y especial sobre los bienes afectos para, con su producto, obtener la satisfacción del crédito. Se mantiene, pues, este rasgo típico de los acreedores con privilegio especial.

Lo expuesto precedentemente es comentado, con la debida autoridad, por Sanjuán y Muñoz ${ }^{53}$, el cual considera, en materia de arrendamiento financiero, que el art. 62.4 LC no podrá ser utilizado, pues la clasificación como crédito especial conllevaría contradicción con los efectos que señala el citado precepto, de conversión de créditos de especiales en créditos contra la masa y de la extracción del bien y el mantenimiento de los créditos vencidos dentro de la masa pasiva.

También ilustra, sobremanera, la Sentencia del Juzgado de lo Mercantil n. 3 , de Barcelona, de fecha 27 de febrero de 2006, que también trata del renting:

«Fundamentos de Derecho. Sexto. Sobre la naturaleza jurídica de los contratos de referencia...

${ }^{53}$ SANJuÁn y MuÑOZ, E., «El arrendamiento financiero como crédito en el concurso», Revista de Derecho Concursal y Paraconcursal, n. ${ }^{\circ}$ 4, 2006, Ed. La Ley, pp. 137-157. 
- En los rentings [las rentas debidas de un contrato de renting con anterioridad a la declaración del concurso tendrán la consideración de crédito ordinario]... los plazos posteriores al concurso se consideran crédito contra la masa respecto de los vencimientos sucesivos.

- En los leasings, las cuotas debidas con anterioridad a la declaración de concurso son deuda concursal, considerada como crédito con privilegio especial sobre los bienes arrendados, y las cuotas vencidas con posterioridad se considerarán deuda contra la masa a medida que vayan venciendo.

El contrato de renting no puede asimilarse, en el ámbito concursal, al contrato de leasing o arrendamiento financiero, por lo tanto no se le debe reconocer privilegio especial alguno al amparo del artículo 90.1.4 de la Ley Concursal...

No deben considerarse vencidos ni incluidos como créditos contra la masa los créditos derivados de los contratos de referencia con anterioridad a que venzan las cuotas».

En el contrato de renting, de naturaleza mercantil y bilateral, una de las partes, la sociedad arrendadora, se obliga a ceder a otra el uso de un bien por un tiempo determinado, a cambio del pago de una renta periódica, cuyo precio incluye el derecho al uso del bien, su mantenimiento y un seguro que cubre los posibles siniestros. Como se deduce de la Sentencia anterior, el arrendador, normalmente arrendador financiero, es decir, la sociedad de renting, cuando el arrendatario fuese declarado en concurso, puede ser acreedor concursal, cuyo crédito será clasificado como ordinario, u ostentar un crédito contra la masa por las cuotas vencidas y no cobradas con posterioridad a la declaración de concurso. En cualquier caso, el arrendador estará legitimado para el ejercicio de las acciones previstas en el art. 62 de la Ley concursal, así como la administración concursal, en caso de suspensión, o el concursado, en caso de intervención, podrán solicitar la resolución del contrato regulada en el art. 61.

\subsection{Suspensión y clasificación de intereses}

Ordena el art. 59: «1. Desde la declaración de concurso quedará suspendido el devengo de los intereses, legales o convencionales, salvo los correspondientes a los créditos con garantía real, que serán exigibles hasta donde alcance la respectiva garantía. Los créditos salariales que resulten reconocidos devengarán intereses conforme al interés legal del dinero fijado en la correspondiente Ley de Presupuestos...».

El Magistrado Sanjuán y Muñoz ${ }^{54}$ señala que en el arrendamiento financiero, el crédito derivado de intereses, como regla general, llega hasta la declaración de concurso, en donde se suspende su devengo con las excepcio-

\footnotetext{
${ }^{54}$ SANJUÁN Y MUÑOZ, E., «El arrendamiento financiero...», op. cit., pp. 137-157.
} 
nes que señala el art. 59 LC. Ello permite, también como regla general, clasificar estos intereses (los devengados hasta la fecha de declaración de concurso y con las citadas excepciones), de conformidad al art. 92.3 LC, como créditos subordinados (cualquiera que sea la clase de intereses, incluidos los moratorios). Los créditos derivados de intereses posteriores al concurso (que quedan suspendidos en cuanto a su devengo) pueden ser pagados, no obstante, cuando se llegue a una solución de convenio sin quita, calculados al interés menor entre el legal y el convencional, y así se recoja en el mismo en pago total o parcial. También serán pagados, esta vez al interés convencional, en los supuestos de liquidación, una vez que se paguen todos los créditos concursales clasificados y siempre que resulte remanente (art. 59.2 LC). La referencia a estos supuestos de intereses cuyo devengo está suspendido parte, por tanto, de la tajante distinción entre los generados hasta la fecha de concurso y los posteriores a la declaración; son estos últimos los que se ven condicionados en cuanto a su suspensión y, posteriormente, a lo que se establezca en un convenio con las características indicadas o una liquidación de la que resulte remanente.

Pues bien, la Sentencia del Juzgado de lo Mercantil n. ${ }^{\circ} 1$ de Oviedo, de fecha 14 de junio de 2005, considera que la clara finalidad a la que atiende la regla de suspensión del devengo de intereses del art. 59 LC es, por un lado, la de inmovilizar en lo posible el pasivo del concurso, evitando que éste siga aumentando durante el transcurso del procedimiento, en perjuicio de la perspectiva de cobro del resto de acreedores, y entorpeciendo notablemente la consecución de una solución concursal, ya sea la convencional o la liquidativa, y de otro lado equiparar en el trato a los distintos acreedores concursales sin hacer de peor condición a los titulares de créditos que no tuvieran a su favor dicho devengo, lo cual conduce a entender que el art. 59.1 LC limita el devengo de intereses postconcursales a los créditos revestidos de genuinas garantías reales, entendidas como derechos constituidos sobre cosa ajena y oponibles erga omnes, y no a otro tipo de créditos, como son los derivados de titularidades dominicales con fines de garantía (arrendamiento financiero, compraventa de bienes con precio aplazado y reserva de dominio), por más que el legislador les haya dispensado un tratamiento asimilado a las garantías reales al revestirles también de privilegio especial, incluyéndolos en el art. 90 LC. Respecto de los intereses moratorios por arrendamientos financieros, declara que los intereses moratorios preconcursales habrán de quedar postergados como crédito subordinado, por disposición del art. 92.3. ${ }^{\circ} \mathrm{LC}$.

De la anterior resolución deduzco que la excepción a la suspensión del devengo de intereses, para los créditos con garantía real, dará lugar al devengo posterior a la declaración de concurso, pero no integrarán el crédito concursal, determinado a la fecha de declaración de concurso, pues aún no se han devengado, es decir, no integrarán la masa pasiva, aunque tampoco tendrán la naturaleza de crédito contra la masa, salvo impago a su vencimien- 
to, por lo que deberá ser objeto de mención en la exposición motivada con la que la administración concluirá su informe (art. 75.3). Para su pago, el convenio no les afectará, si ejercen su derecho de abstención, y en la liquidación estos intereses postconcursales serán satisfechos de acuerdo con el art. 155, hasta donde alcance la respectiva garantía, debido a que el exceso no es exigible y será tratado según previene el art. 59.2, aunque no estoy muy seguro.

\subsubsection{CRÉDITOS COMUNICADOS TARDÍAMENTE}

A la administración concursal corresponde incluir o excluir los créditos en la lista de acreedores, es decir, debe adoptar dicha decisión respecto de cada uno de los créditos comunicados por los acreedores y de los que resultasen de los libros y documentos del deudor o constaren en el concurso (art. 86.1).

El incumplimiento por los acreedores del deber de comunicación de créditos o comunicados tardíamente, cuando no sean incluidos por la administración concursal en la lista de acreedores y los reconozca el juez al resolver sobre la impugnación del informe, serán clasificados como créditos subordinados, salvo que se trate de créditos cuya existencia resultase de la documentación del deudor, constare de otro modo en el concurso o en otro procedimiento judicial, o que para su determinación sea preciso la actuación inspectora de las Administraciones Públicas (art. 92.1. ${ }^{\circ}$ ).

El art. 86.2 obliga a la administración concursal a incluir en la lista de acreedores: a) aquellos créditos que hayan sido reconocidos por laudo o por sentencia, aunque no fueran firmes; b) los que consten en documento con fuerza ejecutiva; c) los reconocidos por certificación administrativa; d) los asegurados con garantía real inscrita en registro público; y, e) los créditos de los trabajadores, cuya existencia y cuantía resulten de los libros y documentos del deudor o por cualquier otra razón consten en el concurso. Se faculta a la administración concursal para impugnar en juicio ordinario y dentro del plazo para emitir su informe, los convenios o procedimientos arbitrales en caso de fraude, conforme a lo previsto en el 53, y la existencia y validez de los créditos consignados en título ejecutivo o asegurados con garantía real, así como a través de los cauces admitidos al efecto por su legislación específica $^{55}$, los actos administrativos.

La administración concursal debe acompañar la mentada lista de acreedores a su informe ex art. 75.2.2. ${ }^{\circ}$, que comprenderá una relación de los incluidos y otra de los excluidos, ordenadas alfabéticamente (artículo 94.1).

${ }^{55}$ Ley 30/92, de 26 de noviembre, de Régimen Jurídico de las Administraciones Públicas y del Procedimiento Administrativo Común. Ley 58/2003, de 17 de diciembre, General Tributaria. Ley 1/1998, de 26 de febrero, de Derechos y Garantías del Contribuyente. 
La decisión de inclusión o exclusión de créditos se adoptará respecto de cada uno de ellos, y se referirá tanto a los comunicados por sus titulares como los que resultaran de los libros y documentos del deudor o por cualquier otra razón constaran en el concurso, según previene el inciso final del párrafo primero del citado apartado 1 del art. 86. Es decir, la administración concursal, aunque el acreedor no hubiese comunicado su crédito, ni acompañado el título o documentos de su crédito (art. 85) o lo hubiese hecho fuera del plazo establecido en el art. 21.1.5. ${ }^{\circ}$, podrá incluirlo en la lista de acreedores, si alcanza evidencia suficiente sobre él, por la verificación de los antecedentes del deudor (libros y documentos) o por cualquier otra razón constaren en el concurso.

Y ¿cuál será la clasificación de estos créditos incluidos en la lista de acreedores de la administración concursal? La que corresponda a su naturaleza, según los arts. 90 a 92. Es decir, si se dan los requisitos del art. 92.1. ${ }^{\circ}$, tendrán el carácter que les corresponda según su naturaleza, sin que influya en su clasificación el hecho de haber sido comunicado tardíamente o no haber sido comunicados.

Así se deduce de la Sentencia del Juzgado de lo Mercantil n. ${ }^{\circ} 1$ de La Coruña, de fecha 7 de septiembre de 2005, al considerar que la postergación del crédito de la Tesorería General de la Seguridad Social, desde el momento en que consta en el concurso, no puede ya sustentarse en el artículo 92.1 de la LC sino, en su caso, en la ubicación concreta del crédito o de partes de éste en alguna de las demás hipótesis del mismo artículo 92.

La Sentencia del Juzgado de lo Mercantil n. ${ }^{\circ} 1$ de Bilbao, de fecha 15 de febrero de 2006, considera que la comunicación tardía de créditos por la TGSS, con causa en el retraso en la comprobación administrativa de la situación deudora del concursado, tiene acomodo en la excepción del art. 92.1, como si de actuación inspectora se tratase, y aunque la administración concursal entienda que no hay inspección, sino un funcionamiento ordinario que seguramente deba modificarse, lo cierto es que precisamente la labor de comprobación de la TGSS es la que permite constatar, con algún retraso, la existencia del crédito, pues esa labor de comprobación no es más que la inspección propia de todo organismo recaudador, de manera que no puede hacerse una hermenéutica restrictiva de quien interviene en defensa de un interés público y ha de considerarse que la excepción del art. 92.1 LC es de aplicación y no se ha comunicado de manera extemporánea la totalidad del crédito. La misma opinión se sostiene en la Sentencia del Juzgado de lo Mercantil de Sevilla, de fecha 7 de febrero de 2006.

El Auto del Juzgado de lo Mercantil n. ${ }^{\circ} 1$ de Madrid, de fecha 10 de marzo de 2005, contempla el siguiente supuesto de hecho:

«Estamos ante la situación en la que el acreedor ha comunicado su crédito con posterioridad a la entrega por parte de la administración concursal del informe, en cuya lista de acreedores no figura el referido crédi- 
to... En este caso debemos entender que, a los efectos del concurso, el crédito ha desaparecido y por tanto el acreedor pierde el derecho a ser reintegrado con cargo a la masa activa, y queda privado de todos los derechos que el reconocimiento del crédito le conferiría en el concurso. Y ello, sin perjuicio de que dicho acreedor pueda articular los mecanismos procesales que entienda convenientes a los efectos que obtener el reconocimiento de su crédito, lo cual viene abonado por la previsión del artículo 134 LC, el cual extiende, en su caso, los efectos del convenio también a aquellos acreedores que por cualquier causa no hubiesen sido reconocidos como tales en el concurso. De ahí que, habida cuenta del momento procesal en que se encuentra el concurso, deba rechazarse a todos los efectos la comunicación del crédito efectuada por la entidad Telefónica de España, SAU, mediante el escrito presentado en fecha 25 de febrero de 2005, sin que proceda atribuir a tal comunicación efecto legal alguno en el concurso».

La Sentencia del Juzgado de lo Mercantil n. ${ }^{\circ} 1$ de Madrid, de fecha 25 de mayo de 2005, analiza el supuesto de que el término para la comunicación de créditos expire con anterioridad al que corresponde a la administración concursal para la presentación de su informe:

«Podemos contemplar... hipótesis distintas, que derivan de la combinación de los dos plazos... La segunda, que el acreedor comunique su crédito una vez transcurrido el plazo del mes previsto el artículo 21.1.5. ${ }^{\circ} \mathrm{LC}$, pero con anterioridad a la expiración del plazo que la administración tiene para la entrega del informe. La tercera, que el acreedor comunique su crédito transcurrido el plazo que ésta tiene para la presentación de su informe... En la segunda hipótesis, nos encontramos ante lo que la Ley califica como de comunicación tardía de créditos. Las consecuencias que el artículo 92.1 LC anuda a la comunicación tardía de créditos pone de relieve la importancia para el acreedor de comunicar su crédito dentro del plazo que la Ley le concede... para el caso en que el crédito en cuestión no conste de ningún modo en el concurso... la consecuencia para tal crédito será la de su postergación a crédito subordinado... En la tercera, se trata del caso de falta de insinuación del crédito, esto es, bien no comunicado, bien comunicado con posterioridad a la finalización del plazo para la entrega del informe para la Administración concursal. En este caso debemos entender que, a los efectos del concurso, el crédito ha desaparecido y, por tanto, el acreedor pierde el derecho a ser reintegrado con cargo a la masa activa, y queda privado de todos los derechos que el reconocimiento del crédito le conferiría en el concurso... De ahí que, para los créditos no insinuados dentro del término concedido a la Administración concursal para la presentación del informe, excluida la posibilidad de su calificación como de subordinados, no pueda ser otra la consecuencia que la de su exclusión definitiva del concurso».

En la Primera Mesa Redonda del II Congreso de Derecho Mercantil, celebrado en Valencia los días 1 y 2 de diciembre de 2005, sobre «Aspectos jurídicos de la formación de la lista de acreedores», se aborda esta cuestión: 
«¿Qué tratamiento debe darse a la comunicación de créditos posterior a la entrega del informe por parte de la Administración concursal?, ¿podrán dichos acreedores hacer valer su crédito en el concurso de algún modo (ex art. 134 LC)?, ¿de qué modo?». Se propone una interpretación más flexible [una vez expuestas las tesis mantenidas en las anteriores Resoluciones]... Porque la mencionada ley no prevé otra sanción expresa para la insinuación tardía de un crédito que la de su subordinación (artículo 92.1. ${ }^{\circ}$ ), es decir, pasar a engrosar el grupo de los del pago en último lugar, tras la íntegra satisfacción de los créditos ordinarios (artículo 158 de la Ley Concursal). Ahora bien, no soluciona el texto legal el problema cuando el crédito se pone de manifiesto en el concurso una vez ya ha sido cerrada la lista de acreedores elaborada por la administración concursal. Excluirlo del concurso, que es desde luego una de las alternativas, presenta inconvenientes, puesto que: $1^{\circ}$ ) no debe desconocerse la existencia de ningún derecho, aunque se revele con retraso, mientras éste no caduque o prescriba la acción para exigirlo; y $2 .^{\circ}$ ) si se le cerrase su entrada en el concurso, y descartada su extinción -pues la ley no la prevé de modo expreso- supondría reenviarlo a una reclamación extraconcursal que, además de generar nueva litigiosidad contra el concursado, no dejaría claro el encuadre de ese crédito ni respecto a los demás acreedores ni en la ulterior dinámica de cumplimiento del convenio (por ejemplo, por cuanto importe debe ser reconocido y, sobre todo, quién y cómo lo clasifica). Desde luego, si se quiere garantizar la seguridad jurídica no se logra generando más conflictividad... Por lo que el mecanismo de la subordinación, siquiera como consecuencia de la tardía puesta de manifiesto del crédito en un incidente concursal, podría suponer una solución para este tipo de situaciones».

\subsection{Formulación de cuentas anuales por la administración concursal}

Se ha criticado, por algún sector de la profesión contable, que el art. 75.1.2. . $^{\circ}$ encomiende a la administración concursal la formulación de las cuentas anuales correspondientes al ejercicio anterior a la declaración de concurso, si el deudor no las hubiese presentado, cuando el art. 6.3.3. ${ }^{\circ}$ obliga al deudor a presentar las cuentas anuales de los tres últimos ejercicios con la solicitud de declaración de concurso. La respuesta, a mi juicio, debe tomar en consideración: a) el concurso puede ser necesario y el deudor no haber dado cumplimiento al requerimiento para su presentación (art. 21.1.3. ${ }^{\circ}$ ); b) la fecha de solicitud de concurso puede tener lugar durante el primer trimestre posterior al cierre del ejercicio social y, consecuentemente, no haberse formulado las cuentas anuales correspondientes por el deudor ${ }^{56}$.

${ }^{56}$ Según el art. 46, se mantiene el deber de formular las cuentas anuales, después de declarado el concurso, que implica el cumplimiento de lo dispuesto en los arts. 25 a 30 y 34 a 39 del C. de C., sobre llevanza contable, y demás concordantes del TRLSA (arts. 171 a 201), así como en otras Leyes especiales (Cooperativas, Fundaciones, etc.) y en la más reciente Ley 7/2003, de 1 de abril, de la Sociedad Limitada Nueva Empresa, que instaura la 
También se ha cuestionado si es exigible la aprobación de dichas cuentas, formuladas por la administración concursal, por la Junta General de socios, y estimo que resulta obligado por las Leyes de Sociedades, y es posible su convocatoria, pues el art. 48 dispone que durante la tramitación del concurso, se mantendrán los órganos de la persona jurídica deudora, salvo el supuesto en que, a consecuencia de la apertura de la fase de liquidación, se declare el cese de los administradores o liquidadores [Art. 145.3].

Por último, se plantea ¿serán firmadas por la administración concursal? Parece que sí, pues a ella encarga la Ley su formulación.

\subsection{Presentación de informe de la administración concursal}

La presentación del referido informe de la administración concursal dará lugar a la resolución judicial correspondiente, que se formalizará del modo acordado por el Juzgado de lo Mercantil n. ${ }^{\circ} 1$ de Málaga, en Providencia de fecha 30 de junio de 2005: «1.- El anterior informe de la administración concursal, y sus documentos, con el inventario de bienes y derechos, únase a los autos de su razón. 2.- Comuníquese la presentación del informe a las partes personadas, haciéndoles saber que pueden examinar el informe y los documentos complementarios en la Secretaría del Juzgado. 3.- Anúnciese la presentación del informe por medio de edictos que se fijarán en el tablón de anuncios del Juzgado. 4.- En los edictos hágase saber a los interesados que en el plazo de diez días, computado desde la última publicación, podrán impugnar tanto el inventario de bienes y derechos como la lista de acreedores en aquello que estimen les es perjudicial».

Considero que el mencionado informe de la administración concursal deberá unirse a la sección segunda, deduciendo testimonio para llevarlo a las secciones tercera y cuarta, así como, en su caso, a las secciones quinta y sexta.

simplificación de los registros contables (art. 141 Ley de Sociedades de Responsabilidad Limitada), objeto de desarrollo reglamentario por RD 296/2004, de 20 de febrero, que aprueba el régimen simplificado de contabilidad, incluyendo a otros sujetos contables, además de las SRL, al amparo de la autorización legal recibida. También subsiste el deber de auditar las cuentas anuales, aunque se exime a las primeras que se preparen después de la declaración de concurso, excepto para sociedades cotizadas y otras sometidas a supervisión pública. Sin ánimo de polemizar, me he preguntado qué procederá si se solicitase del Registrador Mercantil, al amparo del art. 205 del TRLSA, la designación de la persona o personas que deban realizar la auditoría o el nombramiento de un auditor de cuentas para que efectúe la revisión de cuentas de un determinado ejercicio (las primeras que se preparen después de la declaración de concurso), de una SA o SRL declarada en concurso, y que se regula en los arts. 350 a 362 del vigente RRM. ¿Se mantiene la obligación del depósito de las cuentas anuales en el Registro Mercantil (art. 218 y siguientes del TRLSA)? Parece que sí, a la vista de lo establecido en el art. 48.1, que dispone se mantendrán los órganos de la persona jurídica deudora, entre otros, la junta general de socios o accionistas. 


\subsection{Impugnación del inventario y de la lista de acreedores}

El artículo 95 regula la publicidad del informe y de la documentación complementaria e impone el deber de comunicación a la administración concursal, simultáneamente a la presentación de su informe ex art. 75, es decir, el mismo día, por fax, burofax, correo electrónico, correo certificado con acuse de recibo, etc., pero no a todos los interesados en el concurso sino solamente a los acreedores que hayan sido excluidos, o incluidos sin que hubiesen insinuado su crédito, o incluidos por cuantía inferior a la que reclamaron, o incluidos con calificación distinta a la que pretendieron, explicándoles la situación que les afecta y concediéndoles un plazo de diez días, desde que reciban dicha notificación, para que formulen las reclamaciones que a su derecho convenga. Me parece que el trámite relatado, sobre el plazo de diez días para que estos acreedores puedan formular las reclamaciones que a su derecho convenga, no pugna con el establecido en el art. 96.1, concordante con el art. 95.2, que se refiere expresamente a cualquier interesado. En efecto, el art. 96.1 dispone que cualquier interesado podrá impugnar el inventario y la lista de acreedores, dentro del plazo de diez días, a contar desde la publicación ordenada en el citado art. 95.2, a cuyo fin podrá obtener copia a su costa. Naturalmente, aquí se reconoce el derecho de cualquier interesado, entre los que también se encuentran los referidos en el art. 95.1 y, por supuesto, el deudor, para impugnar el inventario y la lista de acreedores, y para ello disponen de un plazo de diez días, que nada tiene que ver con el anunciado en la comunicación de la administración concursal ex art. 95.1, sino con la del art. 95.2, que se remite al mencionado art. 23 de la Ley. Se concreta el plazo para reclamar a los acreedores que reciban comunicación de la administración concursal, respecto de los otros interesados, sin discriminación alguna. No obstante, estos mismos acreedores o presuntos acreedores, que hayan recibido la comunicación de la administración concursal, por imperativo del art. 95.1, tienen derecho a impugnar el inventario y otros créditos incluidos o excluidos de la lista de acreedores presentados por la administración concursal, y dispondrán del plazo establecido en el art. 96.1.

La impugnación del inventario, por cualquier interesado, podrá consistir en la solicitud de la inclusión o de la exclusión de bienes o derechos, o del aumento o disminución del avalúo de los incluidos, y la impugnación de la lista de acreedores podrá referirse a la inclusión o a la exclusión de créditos, así como a la cuantía o a la clasificación de los reconocidos (concordante con los artículos 89 a 94), y se sustanciarán por los trámites del incidente concursal.

La Sentencia del Juzgado de lo Mercantil n. ${ }^{\circ} 1$ de Madrid, de 5 de julio de 2005, reconoce la legitimación pasiva del deudor, en las demandas incidentales de impugnación de la lista de acreedores, además de la administración concursal, cuando declara que el deudor tiene en el incidente de impugnación de la lista de acreedores la condición de demandado. 
En la Primera Mesa Redonda del II Congreso de Derecho Mercantil, celebrado en Valencia, los días 1 y 2 de diciembre de 2005, sobre «Aspectos jurídicos de la formación de la lista de acreedores», se aborda esta cuestión:

«¿Existen dos cauces alternativos para discrepar de la decisión adoptada por la Administración concursal respecto al reconocimiento y calificación de un crédito (reclamación o impugnación) o sólo existe uno? [...] no puede interpretarse que el acreedor disponga de dos cauces diferentes para hacerlo, por más que el art. 95.1 utilice la expresión "reclamación" y el art. 96 emplee la de "impugnación"; la vía es única, la demanda incidental contra la lista de acreedores, que debe tramitarse como incidente concursal (art. 96.4 de la Ley Concursal). De ahí que resulte exigible cumplir las exigencias formales de una demanda de incidente concursal (arts. 192 y siguientes de la Ley Concursal), incluida la defensa y representación procesal que prevé el n. 3 del art. 184 de la Ley Concursal».

Ayuda a la interpretación sobre los mencionados plazos de impugnación la Sentencia del Juzgado de Primera Instancia n. $^{\circ} 10 \mathrm{y}$ de lo Mercantil de Santander, de fecha 29 de junio de 2005, que sostiene:

«... un acreedor, que se encuentra en cualquiera de las situaciones a que se refiere el artículo 95.1, ha de efectuar la reclamación en el plazo de diez días desde la comunicación que le realice de dichas circunstancias la administración concursal, de modo que si no efectúa esa reclamación en dicho plazo no podrá reclamar posteriormente. Pero cualquier impugnación diferente a la referida a su crédito y, en consecuencia, también la relativa al inventario así como cualquier impugnación que efectúe otro interesado deberá realizarse en el plazo de 10 días desde la última comunicación del 95.2 LC. Esto es lógico puesto que cuando la administración concursal comunica a un acreedor que su crédito ha sido excluido de la lista de acreedores, o incluido sin comunicación previa del crédito o por cuantía inferior o calificación diferente de las pretendidas, la información que le da es únicamente con relación a dicho crédito, pero no respecto a otros posibles créditos de que sean titulares ni mucho menos respecto a la totalidad del inventario y de la lista de acreedores. Ha de tenerse en cuenta además, que la ley no distingue respecto a cada uno de los interesados si están personados o no, de modo que el plazo señalado es aplicable a todos ellos, con independencia de que por encontrarse personados en el concurso tengan conocimiento del informe antes de la última comunicación..., y resulta claro que la finalidad de la ley ha sido establecer para la impugnación del artículo 96 un plazo universal, a contar desde una fecha concreta respecto a todos los interesados, sin más excepciones que la recogida en el artículo 95.1».

Sobre el destinatario de la mencionada comunicación de la administración concursal, se ha suscitado la cuestión relativa a las comunicaciones dirigidas a la Agencia Estatal de la Administración Tributaria, que deben hacer- 
se en la sede oficial de la respectiva Abogacía del Estado y no al domicilio de la Agencia Estatal de la Administración Tributaria, según resuelve el Auto del Juzgado de lo Mercantil n. ${ }^{\circ} 1$ de Madrid, de fecha 24 de noviembre de 2005.

En la Primera Mesa Redonda del II Congreso de Derecho Mercantil, celebrado en Valencia los días 1 y 2 de diciembre de 2005, sobre «Aspectos jurídicos de la formación de la lista de acreedores», se aborda esta cuestión: «La publicación de la resolución que tiene por presentado el informe del artículo 95.2, ¿exige que se haga en el Boletín Oficial del Estado y en un diario de los de mayor difusión de la provincia? Se opta por la tesis estricta, según la cual la presentación del informe se notificará a las partes personadas y se publicará en el talón de anuncios del juzgado».

Según el art. 96.4, dentro de los cinco días siguientes a la notificación de la última sentencia resolutoria de las impugnaciones, contra cuyas sentencias no cabrá recurso alguno (art. 197.3), la administración concursal introducirá en el inventario, en la lista de acreedores y en la exposición motivada de su informe [sobre la situación patrimonial ex art. 75.3] las modificaciones que, en su caso, procedan y presentará al juez los textos definitivos correspondientes, así como una relación actualizada de los créditos contra la masa devengados y pendientes de pago, todo lo cual quedará de manifiesto en la secretaría del juzgado.

Omite la Ley la tramitación de referido texto definitivo, pero parece razonable que dé lugar a una Diligencia de Ordenación, para su unión a autos en la sección segunda y consiguiente Providencia judicial de traslado a partes personadas ¿sujeta a recurso de reposición? Parece que sí, pues el texto definitivo puede contener errores u omisiones.

El artículo 97, sobre consecuencias de la falta de impugnación, dispone: «1. Quienes no impugnaren en tiempo y forma el inventario o la lista de acreedores no podrán plantear pretensiones de modificación del contenido de estos documentos, aunque sí podrán recurrir contra las modificaciones introducidas por el Juez al resolver otras impugnaciones. 2. Si el acreedor calificado en la lista de acreedores como especialmente relacionado con el deudor [art. 93] no impugnare en tiempo y forma esta calificación, el Juez del concurso, vencido el plazo de impugnación y sin más trámites, dictará auto declarando extinguidas las garantías de cualquier clase constituidas a favor de los créditos de que aquel fuera titular, ordenando, en su caso, la restitución posesoria y la cancelación de los asientos en los Registros correspondientes».

\subsubsection{IMPUGNACIÓN DE CRÉDITOS CONTRA LA MASA}

En la Primera Mesa Redonda del II Congreso De Derecho Mercantil, celebrado en Valencia los días 1 y 2 de diciembre de 2005, sobre «Aspectos jurídicos de la formación de la lista de acreedores», se aborda esta cuestión: 
«¿Se puede acumular a la impugnación de créditos de la lista de acreedores, la impugnación por inclusión o no de créditos contra masa? [...] existen razones de claridad, sistemática y orden que justifican que no se tramiten conjuntamente, al ser la sección tercera donde se tramitan en tanto que las relativas a la impugnación ex art. 96 en la cuarta (art. 183). En sentido contrario se puede alegar que no hay incompatibilidad así como razones de economía procesal y celeridad, a fin de evitar duplicidad de vista (si esta se admite)».

El Juzgado de lo Mercantil número 1 de Las Palmas, en Sentencia de fecha 15 de septiembre de 2005, resuelve el incidente concursal, seguido a instancia de la AEAT, de impugnación de la lista de acreedores elaborada por la Administración Concursal, por la existencia de un procedimiento de comprobación correspondiente a retenciones por rendimientos del trabajo, IRPF 2004, con el resultado de una cuota a ingresar por dicho concepto (crédito concursal), cuya falta de ingreso en plazo por la entidad concursada ha dado lugar a la apertura del correspondiente procedimiento sancionador por infracción tributaria muy grave, procedimiento concluido el 27 de abril de 2005, mediante acuerdo por el que se considera cometida la citada infracción y, en consecuencia, se impone una sanción por importe de... euros, que considera crédito contra la masa, con arreglo al art. 84.2.10. ${ }^{\circ}$ de la LC, nacido con posterioridad al auto de declaración de concurso, por lo cual, no procede su inclusión en la lista de acreedores pero sí su satisfacción con arreglo a lo establecido en el art.154 de la LC. Se desestima la demanda por dos motivos: «1. ${ }^{\circ}$. Porque el crédito reclamado por la actora no tiene la consideración de obligación nacida de la Ley. $2^{\circ}$. Porque, aun admitiendo que el referido crédito pudiera incluirse en el número $10 .^{\circ}$ del artículo 84.2 de la Ley Concursal, la fecha a tener en cuenta para determinar cuando surge la obligación legal no sería la de la resolución que fija e impone la sanción sino la del día en que tuvo lugar el incumplimiento de la obligación tributaria que dio lugar a esa sanción».

\subsubsection{DEMANDAS INCIDENTALES DE IMPUGNACIÓN}

En la Primera Mesa Redonda del II Congreso de Derecho Mercantil, celebrado en Valencia los días 1 y 2 de diciembre de 2005, sobre «Aspectos jurídicos de la formación de la lista de acreedores», se aborda la siguiente cuestión: «Si la administración concursal en el procedimiento abreviado está constituida por un solo profesional del área económica, en caso de impugnación ¿es imprescindible la asistencia letrada, -artículo 184-? ¿son posibles otras fórmulas para evitar encarecer el proceso y que el administrador concursal puede defender su informe? El art. 184 es claro al exigir en los incidentes la asistencia de letrado. Si el único administrador es del área económica se le priva de intervenir en los incidentes, salvo que contrate un abogado a cargo de la masa... Otra posibilidad es requerirle que sobre la cuestión suscitada emita informe vía art. 35, sin que ello implique otor- 
gar la cualidad de contestación ni la condición de interviniente en el incidente, al ser preceptiva la asistencia letrada. Si no se impugna la providencia requiriendo el informe, no parece que después pueda invocarse nulidad».

Otra cuestión tratada en el mencionado II Congreso de Derecho Mercantil, se refiere:

«En caso de impugnación de la calificación de un crédito, ¿es posible fijar en sentencia una calificación distinta a la mantenida por las partes y a la que aparece en el informe del artículo 74, por considerar que es la que procede en derecho? Son dos las posturas a mantener:

I) aplicación estricta del principio dispositivo: si se impugna, debe el juzgador pronunciarse sobre si la pretendida por el impugnante es correcta; en caso afirmativo estimar la petición y calificar con arreglo a esa petición; en caso contrario desestimar la impugnación y estar a la calificación del informe al ser la administración concursal el órgano al que la ley otorga competencia inicialmente para la calificación, en evitación de que una distinta calificación de oficio pudiera provocar indefensión a los interesados por esa nueva calificación.

II) aplicación del principio iura novit curia: si no se impugna no puede el juez modificar de oficio la calificación, pero una vez cuestionada la calificación, no vemos obstáculo alguno para calificar los créditos con arreglo a los criterios legales que se consideran procedentes, sin necesidad de ajustarse necesariamente al criterio apuntado por el impugnante o el mantenido en el informe [administración concursal], ya que al juez le corresponde aplicar el derecho que estime procedente, haya sido o no invocado por las partes. Parece más conveniente esta última».

A modo de despedida, reitero que el exceso de paginación ha obligado a diferir la materia relativa al convenio y a la liquidación, así como el tratamiento de la calificación, para su posterior publicación, si la Dirección de la Revista lo tiene a bien, y que permaneceré a la espera, durante los próximos meses, para conocer las Resoluciones de las Audiencias Provinciales, alguna especialista de lo Mercantil, como la Sección correspondiente de la de Madrid, sobre las apelaciones planteadas contra algunas de las Sentencias a que he hecho referencia, y que D. m. pueda ofrecerles su recopilación. 